\title{
Including married adolescents in adolescent reproductive health and HIV/AIDS policy
}

Judith Bruce

Population Council

Shelley Clark

Follow this and additional works at: https://knowledgecommons.popcouncil.org/departments_sbsr-pgy

Part of the Family, Life Course, and Society Commons, Gender and Sexuality Commons, International Public Health Commons, and the Medicine and Health Commons

How does access to this work benefit you? Let us know!

\section{Recommended Citation}

Bruce, Judith and Shelley Clark. 2004. "Including married adolescents in adolescent reproductive health and HIV/AIDS policy," paper prepared for the WHO/UNFPA/Population Council Technical Consultation on Married Adolescents. New York: Population Council. 


\title{
Including Married Adolescents in Adolescent Reproductive Health and HIV/AIDS Policy
}

\author{
Paper prepared for the WHO/UNFPA/Population Council \\ Technical Consultation on Married Adolescents, \\ WHO, Geneva, 9-12 December 2003
}

\author{
Judith Bruce \\ Director of Gender, Family, and Development \\ International Programs Division \\ Population Council \\ jbruce@popcouncil.org
}

\author{
Shelley Clark \\ Assistant Professor \\ Harris Graduate School of Public Policy \\ University of Chicago \\ sclark1@uchicago.edu
}

Acknowledgments: We are particularly grateful to Annie Dude, University of Chicago, who provided valuable and extensive assistance compiling the tables. We also wish to acknowledge the financial support of the World Health Organization, the Bill \& Melinda Gates Foundation, the U.K. Department for International Development, The Ford Foundation, and The John D. and Catherine T. MacArthur Foundation, all of which have supported a broad investigation into the conditions of married adolescents' lives. In addition, we thank Population Council staff members Amy Joyce, Rachel Goldberg, and Erica Chong for their help in preparing this manuscript. 


\section{Contents}

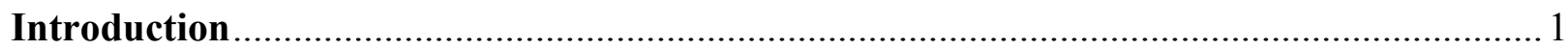

The Traditional Omission of Married Adolescents ........................................................ 2

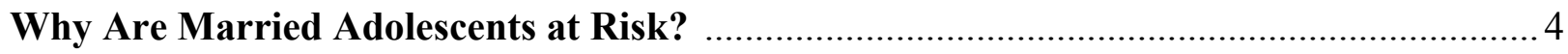

Early Marriage Brings Intensified, and Often Riskier, Sexual Exposure ............................ 4

Social Isolation, Lack of Opportunity, and Low Status .............................................. 6

Identifying the Policy Gap with Respect to HIV and Married Adolescents ...................... 9

Marginalisation of Married Adolescents in Prevailing Adolescent Sexual

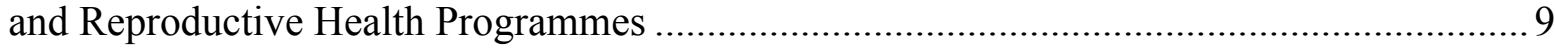

Lack of Prioritising Adolescents Within Safe Motherhood and MCH Programmes ............ 10

Common HIV/AIDS Protection Messages Are Often Inappropriate

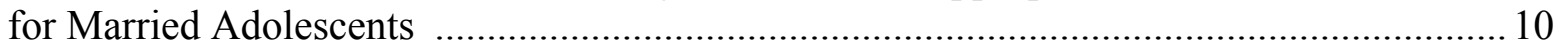

\section{Exercises to Guide Country-Specific Assessments of HIV Risks}

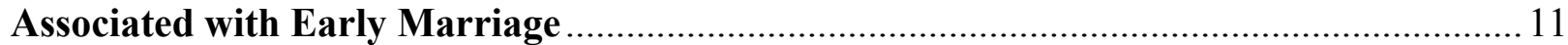

Estimating Levels and Distribution of HIV/AIDS in the Current Population..................... 12

Determining Prevalence of Early Marriage for the Entire Country

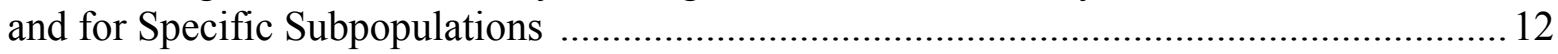

Determining the Magnitude of the HIV Risks Accompanying Early Marriage .................. 13

Percent of unprotected sexual activity occurring within marriage compared

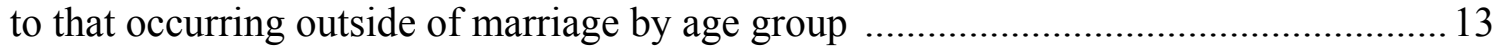

Mean age difference between married/unmarried adolescent girls and their partners .... 13

Assessing the Availability of and Access to Programmes and Services

for Married Women, Particularly Younger or Newly Married Women ............................. 14

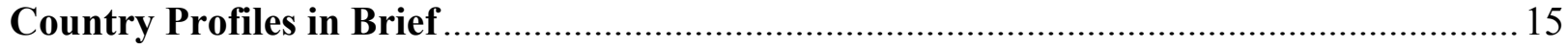

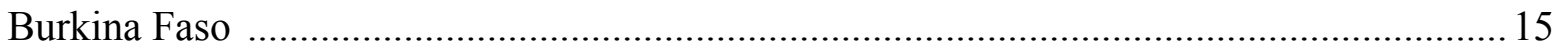

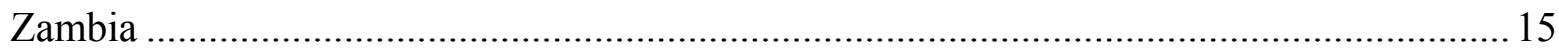

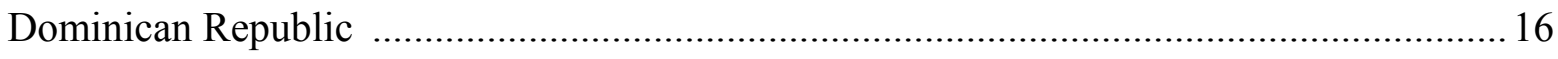

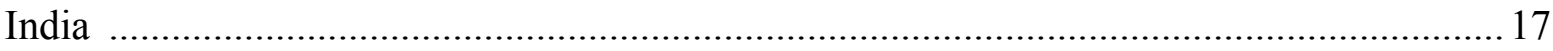

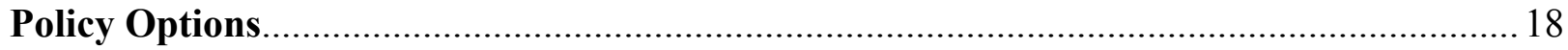

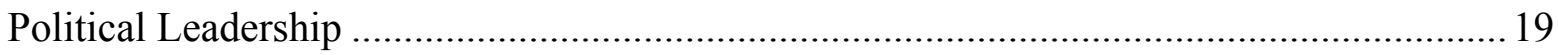


Premarriage Options

Evaluating the legal basis for eliminating underage/child marriages

Developing community-based initiatives that redefine acceptable ages of marriage and offer incentives to parents and girls to delay marriage to legal age ........................20

Raising public awareness that marriage is not necessarily a safe place ........................22

Emphasising the importance of safe, age-appropriate spouses ..................................... 23

Weighing whether later marriage will plausibly expand the number of unmarried, sexually active, and at-risk adolescents .............................................. 24

The Marriage Transition .............................................................................................. 24

Drawing on the sacred associations of marriage to communicate about

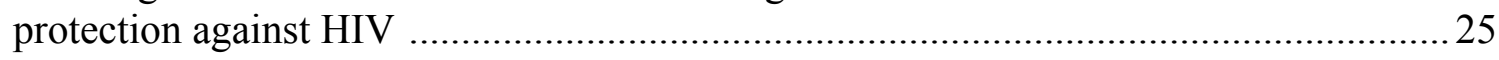

Offering voluntary counseling and testing at the time of marriage ............................25

Redefining the First Year of Marriage as a Health Zone ..................................................26

Fostering more intimate and trusting relationships between new spouses ....................26

Decreasing the imminent pressure for pregnancy ............................................... 27

Destigmatising condoms and protection from STIs/HIV within marriage..................... 28

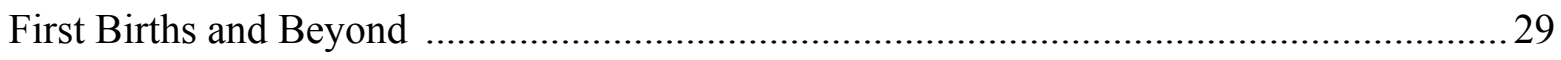

Refining maternal health and adolescent sexual and reproductive health services to bring married adolescents into the circle ..........................................................29

Creating awareness of HIV and enhancing safety within marriage through services at first birth .29

Summary 30

Tables 


\section{INTRODUCTION}

In the past decade policy attention has turned toward adolescent reproductive health, and social development issues have begun to take centre stage in international development policy. During that same decade, the shape of the HIV epidemic shifted, with women of all ages now comprising half of those infected with HIV/AIDS. Much of that acceleration in the spread of HIV among women has taken place among adolescents. In some parts of the world, most notably sub-Saharan Africa, HIV prevalence rates among young women aged 15-24 outpace those of men in that age group by two to eight times. ${ }^{1}$ Of substantial consequence, yet largely ignored, is the fact that the majority of sexually active girls aged 15-19 in developing countries are married (see Table 1, Columns 2 and 3$)^{2}$ and these married adolescent girls tend to have higher rates of HIV infection than their sexually active, unmarried peers. ${ }^{3}$ Thus married adolescent girls not only represent a sizeable fraction of adolescents at risk, but they also experience some of the highest rates of HIV prevalence of any group.

Nonetheless, married adolescents have been marginal in adolescent HIV/AIDS policies and programmes and have not been the central subjects for programmes aimed at adult married women. ${ }^{4}$ We suggest that it is time - indeed past time - to give substantially greater attention to the process of marriage and, specifically, the role that early marriage plays in potentially exposing girls and young women to severe reproductive health risks, including HIV. Our arguments and analyses suggest that married adolescents represent an acutely underserved group, who in the context of an HIV epidemic are especially vulnerable. Epidemiological analyses have failed to appreciate the importance of HIV prevention to young married women who are unlikely to spread the disease through peer interactions. Yet, protecting these young women not only serves to help prevent the disease from spreading from "high-risk" groups like sex workers and truck drivers to the general population in their own generation, but also to the next generation by reducing mother-to-child-transmission among this most intensive childbearing group. ${ }^{5}$

In the next section, we offer a partial explanation for why married adolescents have so often been overlooked. We then articulate the reasons why marriage, and particularly early marriage, might bring elevated risk of HIV. After demonstrating a gap in HIV/AIDS policies for married adolescents, we turn our attention to the implications and provide initial analytic tools to assist policymakers in determining how to accord appropriate levels of priority to the marriage process

\footnotetext{
${ }^{1}$ Laga, M., B. Schärtlander, E. Pisani, P.S. Sow, and M. Caraël. 2001. "To stem HIV in Africa, prevent transmission to young women," AIDS 15(7): 931-934; and UNAIDS. 2000. Report on the Global HIV/AIDS Epidemic.

Washington, DC: UNAIDS.

${ }^{2}$ This statement excludes China, where marriage is typically later and data are missing.

${ }^{3}$ Clark, Shelley. 2004. "Early marriage and HIV risks in sub-Saharan Africa," Studies in Family Planning, 35(3): 149-160; Glynn, J.R., M. Caraël, B. Auvert, M. Kahindo, J. Chege, R. Musonda, F. Kaona, and A. Buvé for the Study Group on Heterogeneity of HIV Epidemics in African Cities. 2001. "Why do young women have a much higher prevalence of HIV than young men? A study in Kisumu, Kenya and Ndola, Zambia," AIDS 15(suppl 4): S51S60; and Kelly, R.J., R.H. Gray, N.K. Sewankambo, D. Serwadda, F. Wabwire-Mangen, T. Lutalo, and M.J. Wawer. 2003. "Age differences in sexual partners and risk of HIV-1 infection in rural Uganda," Journal of Acquired Immune Deficiency Syndromes 32(4): 446-451.

${ }^{4}$ Because early marriage is a largely female phenomenon, and little data exist on married boys, this paper focuses on the situation of married girls.

${ }^{5}$ Childbearing is expected soon after marriage. Indeed, while age at marriage has generally increased, the average number of months between marriage and first birth has decreased in all regions. Source: Mensch, Barbara. 2003.

"Trends in the timing of first marriage," paper presented at the WHO/UNFPA/Population Council Technical Consultation on Married Adolescents, WHO, Geneva, 9-12 December.
} 
and married adolescents in HIV/AIDS prevention efforts. Then, five brief case studies illustrate how the indicators suggested in the previous section can be implemented in specific settings. Lastly, we offer a menu of potential policy interventions and actions to make married adolescents an integral part of reproductive health and HIV prevention initiatives.

\section{THE TRADITIONAL OMISSION OF MARRIED ADOLESCENTS}

Early marriage and the needs of married adolescents have been neglected in the past for historical, legal, and socio-cultural reasons. It is essential to recognise that the adolescent agenda - indeed the concept of "adolescence" itself - originated in Western cultures. Thus, the adolescent policy agenda, in its brief history, has been framed by the priorities and cultural experience of developed countries, where the proportions of married adolescents are relatively low - though the United States ranks among the highest in Western countries at 1.3 percent for boys and 3.9 percent for girls. ${ }^{6}$ Given their small numbers in these countries, married adolescents' needs and conditions have been, at best, a minor consideration. Rather, it has been the experience of unmarried — often in-school — adolescents' sexual initiation, risk-taking behaviours, and, more recently, social environments that have been major themes of both research and policy interventions. In some countries, such as Mexico, where significant priority had been given to unmarried adolescents' behaviours, recent research has begun to show that "marital status and gender are key to understanding sexual behaviour."7

Legally, married adolescents have been sidelined. As international human rights efforts gathered steam, many gender issues, including early marriage, received initially limited attention. Though there have been pro-forma condemnations of early marriage in many international policy documents, premature or involuntary marriages have not been major subjects in the international human rights movement. The Convention on the Rights of the Child (CRC) - the most natural basis for international attention - offers an extremely useful crosscultural definition of "childhood" (up to age 18) and a detailed vision of the needs and rights of children and their evolving capacities; yet it allows countries to apply these rights and protections only to the unmarried. The CRC permits signatory countries to determine whether marriage removes girls (who form the vast majority of married children) ${ }^{8}$ and boys from the protected space of childhood: "A child means every human being below the age of 18 years unless under the law applicable to the child, majority is attained earlier" (Article 1, CRC). ${ }^{9}$

\footnotetext{
${ }^{6}$ While the number of adolescents who are married by age 20 in the United States is relatively low, in some states the number of marriages involving an adolescent is actually quite high. In the state of Utah, for instance, in 1995, 22 percent of marriages involved a bride under 20 years old; nationally the figure was 11 percent. In 1999 in the state of Idaho, nearly 16 percent of all marriages involved a bride under 20 years old. Source: United Nations. 2000. World Marriage Patterns. New York: United Nations Population Division, Department of Economic and Social Affairs.

${ }^{7}$ Vernon, Ricardo. 2003. "Adolescent reproductive health and sex education in Mexico," paper presented at the Youth Reproductive Health and HIV Prevention meeting, Washington, DC, 9 September. He noted that about 50 percent of ever sexually active girls were married.

${ }^{8}$ In nearly all countries girls aged 15-19 are at least twice as likely to be married as boys; sometimes the probability is much higher. For example, in Brazil the probability of marriage for girls is five times higher, while in Indonesia it is seven and a half times higher. In Kenya girls are an astounding 21 times more likely to be married than boys of the same age. Source: United Nations. 2000. See note 6.

${ }^{9}$ For a discussion of the interpretation of early married with respect to the CRC, see the paper by Gabriella de Vita of UNICEF presented at the WHO/UNFPA/Population Council Technical Consultation on Married Adolescents, WHO, Geneva, 9-12 December 2003.
} 
Indeed, some countries might not have signed the $\mathrm{CRC}$ without potential exemption to child rights protection for married girls and women. This legal construction reflects and is justified by a long-standing cultural norm - that marriage, regardless of age, confers adult status. Marriage often marks the passage out of childhood and bestows social seniority and a different set of rights - which may be more or less than those allotted to children.

A third closely related reason for the invisibility of the needs of married adolescents is psychological in nature. The comforting thought that a married girl is "taken care of" and has passed from the "protection" of her natal kin to that of her husband is almost universal. This perception of marriage as a "safe place" may be heightened for parents, and plausibly for girls themselves, who are concerned about the risks to unmarried girls' reputations and sexual "purity" in the context of rapidly changing cultural norms and a growing HIV epidemic. ${ }^{10}$ The concept that marriage provides safety and protection is echoed at high policy levels and among some religious authorities. A recent debate in Trinidad about raising the age of marriage met with objections from a high Hindu official who characterised marriage as a "safety net" for girls. A Muslim colleague, defending a law that allowed 12-year-olds to marry, saw marriage as a means to "protect the child" from unwanted pregnancy. ${ }^{11}$

These historical, legal, and cultural influences, while understandable, have led to a collective denial of the continuing and widespread occurrence of not just "early" but child marriage. Of the 331 million girls currently aged 10-19 who live in the countries of the developing world excluding China, 163 million will be married by their twentieth birthday, if present trends continue. Over the next ten years, more than 100 million girls in those countries will be married before their eighteenth birthday. ${ }^{12}$

Not only are these numerous married adolescents largely invisible to policymakers and programme administrators, but the risks of HIV within marriage, especially marriages characterised by unequal power relations, have been sidelined during the first part of the HIV epidemic. The initial protective strategies were developed in the context of relatively empowered adults having consensual sex who, with support, could communicate well and find the means to avoid pregnancy and infection. The initial successful strategies to protect against HIV addressed the needs of the first wave of infections. In the United States, the epidemic was first reported and gained high visibility among relatively affluent, well-educated men who had sex with men, where pregnancy was not only undesirable but unachievable. In sub-Saharan Africa, the first wave of infections was found among "wealthy men who could afford to travel, have multiple sex partners, and pay for sex."13

Increasingly, however, the epidemic in all regions is moving rapidly among the poor and those powerless to negotiate the terms of sexuality and, as a result, is becoming increasingly selective of young people, especially girls and young women. Strategies that have been effective

\footnotetext{
${ }^{10}$ From a study in Kenya of married girls, a researcher reports "emblematic" attitudes regarding the perception of protection: "I am happy because I have now settled with my husband. I don't go out looking for other partners and I am not at risk of getting STDs, like AIDS" (age 21, married at 18, Nyahururu district). Source: Erulkar, Annabel. 2002. "Married adolescents in Kenya: Exploring the links between marriage and HIV infection," unpublished draft, 11 November; and Erulkar, Annabel and Charles Onoka. 2003. "Tabulations of data from Adolescent and Reproductive Health Information and Services Survey," unpublished, Central Province, Kenya.

${ }^{11}$ Richards, Peter. 1999. "Calling a halt to child marriages," Inter Press Services, 17 August.

${ }^{12}$ Population Council analysis of DHS data, with special thanks to Carey Meyers and Brian Pence.

${ }^{13}$ Kiragu, Karusa. 2001. "Youth and HIV/AIDS: Can we avoid catastrophe?" Population Reports series L, no. 12, Fall. Baltimore: Johns Hopkins University Bloomberg School of Public Health, Population Information Program, p. 5.
} 
to some degree for the previous groups of at-risk populations will not necessarily be appropriate or feasible choices for disempowered young women under pressure to become pregnant (e.g., young married women).

\section{WHY ARE MARRIED ADOLESCENTS AT RISK?}

Girls married before the age of 18 will face significant risks of HIV for two primary reasons. First, crossing the threshold into marriage greatly intensifies sexual exposure via unprotected sex, which is often with an older partner who, by virtue of his age, has an elevated risk of being HIV-positive. Second, marriage changes girls' support systems both inside and outside their households, often leaving them more isolated from external social and public support and in a lower position within their new household.

\section{Early Marriage Brings Intensified, and Often Riskier, Sexual Exposure}

Even as sexual relations outside of marriage are becoming more common in all parts of the world, marriage remains the most common route to regular, sexual relations and their attendant health risks for girls in developing countries. Of equal or greater relevance to HIV/AIDS prevention policies is the fact that sex within marriage - whether formal or common law - is overwhelmingly unprotected with respect to HIV and sexually transmitted infections (STIs). ${ }^{14}$ The dramatic rise in the frequency of unprotected sex when moving across the marital boundary is driven by not only the implication of infidelity or distrust associated with certain forms of contraception, such as condoms, but often also by a strong desire to become pregnant (see below).

In Table 1, Column 2, we find that in most of the 26 countries with data on sexual activity among married and unmarried adolescents the majority of sexually active girls aged 15-19 are married. In an additional five countries (Bangladesh, Egypt, India, Indonesia, and Turkey), we can plausibly assume that more than 80 percent of sexually active girls are married as questions about the sexual activity of unmarried adolescents were deemed either too sensitive or too rare to warrant inclusion in the survey. Of the 31 countries, in only two do married adolescents constitute less than 30 percent of sexually active adolescent girls.

Key to understanding the spread of HIV is the frequency of exposure. By this measure, married adolescent girls' share of risk increases substantially — as they comprise an even larger proportion of girls who had sex last week. Marriage appears across the board to increase the frequency of sex with the proportion of married girls who had sex last week higher than the proportion married among sexually active girls in every country (Table 1, Column 2 vs. Column 3). Part of this increase in frequency may be attributed to access to privacy and availability of a partner, but part may also result from greater coerced or forced sex, as sex is plausibly less voluntary within marriage since it may be more difficult to say "no" to a husband than to a boyfriend (see Table 5, Column 9, for percentage of wives who say it is okay for husbands to beat their wives if they refuse to have sex with them).

\footnotetext{
${ }^{14}$ In developing countries, between 2 percent and 6 percent of married couples use condoms. Source: Gardner, R., R.D. Blackburn, and U.D. Upadhyay. 1999. "Closing the condom gap," Population Reports series H, no. 9, April. Baltimore: Johns Hopkins University Bloomberg School of Public Health, Population Information Program.
} 
Even more disconcerting, in terms of HIV risk, is that not only do married girls have sex more frequently, but these encounters are much less likely to be protected with condoms. On average across these 31 countries, 80 percent of unprotected sexual encounters among adolescent girls occurred within marriage. South Africa has by far the lowest percentage of unprotected sex occurring within marriage (13 percent), while in Gabon and Ghana about half of unprotected sex is among married adolescent girls (53 percent and 49 percent, respectively). In all other countries, between 68 percent and 100 percent of unprotected sex last week happened in marriage (Table 1, Column 4). Columns 5 and 6 of Table 1 report the proportion of married and unmarried girls who had unprotected sex last week. We can use these percentages to calculate the risk of a married girl having unprotected sex last week relative to the risk of an unmarried girl. Table 5 shows that the relative risk of having unprotected sex last week for married girls compared to unmarried girls ranges from 4.4 in South Africa to over 100 in Nicaragua to nearly 500 in Rwanda.

The desire to become pregnant substantially explains these dramatic differences in levels of unprotected sexual exposure, since there are currently no available methods that protect against HIV but do not prevent conception. Not surprisingly, Table 2 shows that nulliparous married adolescents are significantly more likely to desire to become pregnant in the next two years than nulliparous unmarried sexually active girls, with about half of nulliparous married girls seeking pregnancy compared with less than 15 percent of nulliparous unmarried girls. Interestingly, nulliparous married adolescents seeking pregnancy have a higher sexual frequency than married adolescents desiring a second or higher order birth.

Yet desire to, or even pressure to, become pregnant does not account for all of the difference in frequency of unprotected sex, as shown in Table 3. Married adolescents were significantly more likely to have had unprotected sex last week, regardless of pregnancy intentions. Although this difference is much greater among girls who do not wish to become pregnant, even among girls who are actively seeking pregnancy in the next two years, married girls were on average three times as likely to have had unprotected sex last week. These results suggest both that frequency of sex increases in marriage and that condom use is much less common (and probably less acceptable) as a means of preventing a birth within marriage than outside of marriage. Thus, the added, if unintentional, benefit of condom use for contraceptive purposes - their protection against HIV and other STIs - is lost for married adolescents under pressure to become pregnant.

Apart from having more frequent unprotected sex, married adolescent girls are also likely to have older partners, who are more likely to be HIV-positive. The increase in the numbers of young females infected with HIV has led some policymakers and researchers to conclude that large age differences in sexual partners leave adolescent girls at particular risk of infection. Much media attention and some adolescent reproductive health informational efforts have identified relationships between young single girls and their older "sugar daddies" as risky. ${ }^{15}$ In reality, in parts of sub-Saharan Africa at least, husbands of adolescent girls tend to be older than the partners of unmarried sexually active adolescent girls. ${ }^{16}$ Large age differences between husbands and young brides (women married before the age of 20) are common, ranging from 4.7 years in Guatemala to 14.1 years in Guinea. Indeed, the younger a bride is at the time of marriage the greater her age difference with her spouse (Table 4, Columns 6 and 7). For example

\footnotetext{
${ }^{15}$ Luke, Nancy and Kathleen M. Kurz. 2002. "Cross-generational and transactional sexual relations in sub-Saharan Africa: Prevalence of behavior and implications for negotiating safer sexual practices." AIDS Mark report. Washington, DC: International Center for Research on Women and Population Services International.

${ }^{16}$ Clark. 2004. See note 3 .
} 
in the West African countries, women who marry before age 20 are on average 10.9 years younger than their husbands, while women who marry after age 20 are 8.7 years younger. In Latin America, too, young brides marry relatively older men than older brides; the average age difference for women marrying before age 20 is 5.9 years, while it is 3.4 years for those marrying later.

A concern about large age gaps between sexual partners is increasingly present in national AIDS policies. Yet these policies often fail to acknowledge the role of marriage in creating and entrenching such large age differences. For example, the 2002 national AIDS report from Ethiopia - issued every two years by the Federal Ministry of Health — notes the higher infection rate for females aged 15-19 over males, attributing it to "earlier sexual activity among females and the fact that they often have older partners" (p. 16). ${ }^{17}$ The same report makes no mention ${ }^{18}$ of marriage or specifically early marriage, although Ethiopia has a notably low age of marriage, especially in some regions. ${ }^{19}$ In Amhara region, two of the four urban sentinel sites report the highest HIV-positive rates among pregnant women in the entire country (19.9 percent and 23.4 percent compared to 13.3 percent as the national urban average) while 50 percent of the girls in this region were married under age $15 .^{20}$

Not only are husbands, on average, older than boyfriends, they are also more likely to be infected. Clark (2004) calculates that in Kisumu, Kenya, 30 percent of male partners of married adolescent girls were infected with HIV, while only 11.5 percent of the partners of unmarried girls were HIV-positive. ${ }^{21}$ She finds that similarly, in Ndola, Zambia, 31.6 percent of married girls' partners compared to 16.8 percent of unmarried girls' boyfriends were found to carry HIV. In many countries, depending on the stage of the epidemic, men aged 25-35 are significantly more likely to have HIV, as well as other STIs such as HSV-2, than are younger men aged 1524. Thus, though we may need to be wary of the traditional meaning of "sugar daddy," the largest concentration of "sugar daddies" in our midst — albeit largely unacknowledged - are the husbands of married adolescent girls.

\section{Social Isolation, Lack of Opportunity, and Low Status}

Married adolescent girls' increased unprotected sexual activity, pregnancy-seeking status, and older partners are not the only features of their lives that put their health in jeopardy. Marriage, in most cases, removes girls from significant opportunities, freedoms, and rights, many of which are guaranteed under the CRC. ${ }^{22}$

\footnotetext{
${ }^{17}$ AIDS in Ethiopia, 4th ed. 2002. A report from the POLICY Project, Disease Prevention and Control Department of the Ministry of Health, Ethiopia.

18 The authors spoke with a number of the contributors to the Ethiopia AIDS report and there is indication that attention will be given to marriage, including early marriage, in the next review.

19 The median age at first marriage in Ethiopia is 15.8 years. This calculation is based on data from women over 30 years of age, since nearly all women are married by this age.

${ }^{20}$ Data are for 20-24-year-olds. Source: Central Statistical Authority and ORC Macro. 2001. Ethiopia Demographic and Health Survey 2000. Addis Ababa and Calverton, MD: Central Statistical Authority and ORC Macro.

${ }^{21}$ Clark. 2004. See note 3.

${ }^{22}$ The rights guaranteed under the CRC, which may be curtailed by early marriage, include:

- the right to education (Article 28);

- the right to be protected from all forms of physical or mental violence, injury, or abuse, including sexual abuse (Article 19) and from all forms of sexual exploitation (Article 34);

- the right to rest and leisure, and to participate freely in cultural life (Article 31);

- the right to seek, receive and impart information and ideas (Article 13); and
} 
Social isolation is a loss in its own right and is increasingly identified as a predisposing factor for HIV risk as it undermines the benefits of "social cohesion." Social contact and networks are becoming widely recognised as vital to transmitting information and supporting behaviour change. Some analysts have credited part of Uganda's success in reducing HIV infections to its superior "social capital" and "cohesion" (supported by leadership at the top). Stoneburner and colleagues find support for the hypothesis that "[e]lements of social capital and cohesion served as catalysts to convert AIDS knowledge to personal modification of sexual lifestyles in Uganda [emphasis added]. ${ }^{23}$ Ugandans are more likely to receive AIDS information through personal friendship networks," which may "more effectively personalize risk and result in greater behavioral change." 24

In most countries, however, married girls report marriage as lonely, cutting them off from friends and family, restricting social and geographic mobility, and limiting access to information, schooling, and community participation. Marriage is often accompanied by a dramatic increase in their workload. ${ }^{25}$

The Self-Employed Women's Association in Ahmedabad, India-a highly successful organisation of mass mobilisations of women - sponsors a livelihood programme for both married and unmarried adolescent girls. Coordinators of the project, describing the great difficulty of engaging married girls, report that married girls" "autonomy and mobility is even more limited than unmarried girls and adult married women" (p. 6). ${ }^{26}$ A First-Time Parents project, operated by the Population Council with partners in Gujarat and Calcutta, found a marked reduction in reported friends when girls moved from their natal to their marital homes; 96 percent of married girls in Gujarat and 25 percent in West Bengal said that they had had friends when they lived in their natal homes, while only 67 percent and 7 percent, respectively, reported having friends in the current marital home. ${ }^{27}$ Baseline studies in Bangladesh compared the spatial and social mobility of girls (married and unmarried) and boys (married and unmarried). Among unmarried girls, 88.8 percent reported that they "have many friends in the area" in contrast to only 40.5 percent of married girls. ${ }^{28}$

Intriguingly, married adolescent girls' isolation may extend to their access to media. Initial reports from Asia (Indonesia and Nepal) suggested that married adolescent girls are more likely to be outside the reach of radio and television. In rural Nepal, a smaller percentage of married females aged 14-22 reported ever having watched television compared to single females in the same age group. ${ }^{29}$ This gap may be crucial as media and schools are increasingly enlisted to

\footnotetext{
- the right to educational and vocational information and guidance (Article 28).

${ }^{23}$ Stoneburner, Rand, Daniel Low-beer, Tony Barnett, and Alan Whiteside. 2000. "Enhancing HIV protection in Africa: Investigating the role of social cohesion on knowledge diffusion and behavior change in Uganda," presentation at the XIII International AIDS Conference, Durban, South Africa, 9-14 July.

${ }^{24}$ Stoneburner et al. 2000. See note 23.

${ }^{25}$ Diop, Nafissatou and Jacqueline Cabral N'Dione. 2002. "Senegal: Diagnostic study on the life experience of married adolescent girls." New York: Population Council.

${ }^{26}$ SEWA/Population Council. 2003. "Building livelihood skills and opportunities for adolescent girls in Ahmedabad and Vadodara districts," baseline survey results. Gujarat, India: SEWA/Population Council.

${ }^{27}$ Santhya, K.G., F. Ram et al. 2003. "The gendered experience of married adolescent girls in India: Baseline findings from the First-Time Parents project," paper presented at the 2nd Asia Pacific Conference on Reproductive and Sexual Health, Bangkok, 6-10 October.

${ }^{28}$ Department of Women's Affairs. 2002. "Baseline survey report on rural adolescents in Bangladesh: Social life." Dhaka: Ministry of Women's and Children's Affairs, Government of the People's Republic of Bangladesh, October.

${ }^{29}$ Thapa, Shyam and Vinod Mishra. 2001. "Mass media exposure among urban youth in Nepal," Population \& Reproductive Health, NAYA Report Series no. 10. Kathmandu: Family Health International, May (revised July).
} 
convey HIV prevention messages and support HIV programmes. Finally, a social mapping exercise undertaken in Burkina Faso found markedly different patterns of use of public space among married girls compared to single girls. Married girls effectively had access only to public places that served as a function of their duties as a wife and mother, such as health centres, churches/mosques, markets, and the water pumps. ${ }^{30}$

Married girls are also highly unlikely to be in school, which is an important setting in which much of adolescent and HIV policy is mounted (see Tables 5 and 6 for more information). The imbalance of attention to the schooling needs of married adolescent girls is evident in policies governing who can or is encouraged to return to school. In South Africa, as in a number of countries, there has been explicit policy change to encourage girls with babies to return to school, but no parallel efforts have been made to keep married girls in school (regardless of their childbearing status). Consequently, an estimated 45 percent of unmarried girls with babies are in school as compared to 27 percent of married girls. ${ }^{31}$ Similarly, in several countries, including Brazil, married girls without children (12.8 percent) are even less likely than unmarried girls with children (29.8 percent) to be in school (see Table 6). Further evidence that early marriage diminishes educational achievement can be seen in Columns 10 and 11 of Table 5; married adolescent girls in all countries are less likely to be in school than their single counterparts.

The low status of young brides in their new households may also exacerbate their vulnerability to HIV. Given the typically large age gap with their husbands, younger wives have even less negotiating power over when to have children; their preferred type of contraception, particularly condoms; and their ability to refuse sex. They may also have less ability to demand fidelity or to leave husbands they suspect or know are unfaithful. These young wives may also feel more keenly pressure to have a child as quickly as possible to secure their position among their husbands' kin. A study of married adolescent girls in Kenya highlighted the physical control imposed on girls by husbands. Seven percent of girls reported that their husbands had hit them in the past month. One young woman, age 23, married at age 17, in Nyeri district said, "I didn't like the way he controlled me, like I was a toy. And on top of that, the weekly beatings he gave me. He had warned me against having a friend.",32

Married adolescent girls' relative isolation from information and services as well as their low status within the household limit their knowledge about HIV/AIDS and impinge on their ability to heed HIV messages. In most countries married adolescent girls are as likely or less likely to have heard of HIV compared to single, sexually active girls, and they are even less likely to know a way to avoid AIDS (Table 5, Columns 1-4). Moreover, while the overwhelming majority of married adolescents report having only one partner or doing nothing in response to concerns about HIV, single girls drew on a wider range of protection strategies, including having only one partner, using condoms, stopping all sex, or not initiating sex. In India, there is some evidence that married women have very little exposure to AIDS messages. According to the 1998-99 National Family Health Survey (NFHS-2), "only 40 percent of ever-married women in India had ever heard of AIDS, much less knew how to prevent it" (p. 4). ${ }^{33}$ Even fewer married adolescents (29.7 percent) had heard of HIV (Table 5).

\footnotetext{
${ }^{30}$ Saloucou, Lydia and Martha Brady. 2003. "Community mapping exercise of public spaces for adolescents: Tools for program planning." New York: Population Council.

${ }^{31}$ Roberts, Benjamin. 1999. School of Development Studies, UND from South Africa Statistics 1996 Census, 10 percent sample; special tabulations prepared for the Population Council.

${ }^{32}$ Erulkar. 2002. See note 10.

${ }^{33}$ Brown, Tim. 2002. "The HIV/AIDS epidemic in Asia," Asia-Pacific Population and Policy no. 60. Honolulu: East-West Center, Population and Health Studies, January (published in April).
} 


\section{IDENTIFYING THE POLICY GAP WITH RESPECT TO HIV AND MARRIED ADOLESCENTS}

Not only are married adolescent girls often isolated within their new households and from external public and private support, but their needs have not been prioritised or sometimes even considered in current reproductive health initiatives. Moreover, many of the most common HIV/AIDS policies and messages are not appropriate for them.

\section{Marginalisation of Married Adolescents in Prevailing Adolescent Sexual and Reproductive Health Programmes}

Adolescent reproductive health programming reflects the bias of adolescent programming in general, that is, directing most, or even exclusive, attention to the needs of unmarried adolescents. Four main types of adolescent reproductive health programmes consume the vast majority of adolescent reproductive health resources: family life education programmes that include HIV/AIDS education, youth centres, peer education as a primary communication strategy, and youth-friendly health services.

As mentioned above, married girls often have received no schooling or are early school leavers and consequently may not receive the benefits of family life education. Girls in general, and certainly married girls, are either not served or are less well-served in youth centres than males, particularly older, often nonadolescent males. The configuration of these youth centres often actually discourages female participation. ${ }^{34}$ Peer education programmes, which have become increasingly popular, often operate without clear theories of how change takes place within different peer groups and even often fail to define "peer." 35 Evaluations of their effectiveness fairly systematically identify the main benefits as being to the promoters themselves. One of the few studies to track closely the characteristics of promoters, in this case in Ghana, noted there were no married peer educators (among 106) and only 6 percent of the contacts (among 526) were with married individuals. ${ }^{36}$ As the above data on married adolescent girls indicate, they have distinctive patterns of social mobility and more limited social networks than unmarried girls, placing them arguably outside the reach of conventional peer-to-peer programmes.

Some youth-serving organisations are beginning to track more carefully which youths they serve, looking to define unmet need among different age, gender, schooling, and marital status groupings. Fifteen such NGOs in Ethiopia recently undertook a six-week experiment to track their service contacts. These valuable and needed services were highly concentrated among older adolescent male, in-school, unmarried "youth," and appeared to give only minimal attention to

\footnotetext{
${ }^{34}$ Erulkar, Annabel. 2003. "Examining the gender dimensions of popular adolescent programs: What they could offer adolescent girls and boys," in Adolescent and Youth Sexual and Reproductive Health: Charting Directions for a Second Generation of Programming, background document for a workshop of UNFPA in collaboration with the Population Council. New York: Population Council.

${ }^{35}$ Erulkar. 2003. See note 34.

${ }^{36}$ Wolf, R. Cameron, Katherine C. Bond, and Linda A. Tawfik. 2000. "Peer promotion programs and social networks in Ghana: Methods for monitoring and evaluating AIDS prevention and reproductive health programs among adolescents and young adults," Journal of Health Communication 5(suppl): January.
} 
the subset of young, married girls who are arguably one of the largest groups at risk of poor reproductive health outcomes - maternal morbidity and mortality and STI, even HIV, infection. ${ }^{37}$

Finally, and paradoxically, youth-friendly health services, meant to be a major means of improving adolescent reproductive health, are largely contraceptive services with some STI and HIV information, counseling, and testing included and, where available, treatment. Adolescent reproductive health programmes to date still give scant attention to marriage preparation and often explicitly exclude antenatal, delivery, and postpartum care as key services.

We queried 26 key informants from 17 international organisations with extensive knowledge of HIV and adolescent reproductive health programmes in a multitude of countries about these programmes. Encouragingly, youth-oriented and HIV/AIDS prevention campaigns are burgeoning. They reflect a range of diverse and often highly creative programmes that frequently have a far-reaching impact. Although very few of these programmes keep detailed records of the groups they have reached or served, most acknowledged that they have had very few married adolescents among their clientele. Indeed, while these activities geared toward adolescents are too innumerable to describe, respondents could not identify programmes that specifically target married adolescents or have developed specific messages for them.

\section{Lack of Prioritising Adolescents Within Safe Motherhood and MCH Programmes}

Apart from adolescent sexual and reproductive health services, there are other key avenues to reaching married adolescents via safe motherhood initiatives or maternal and child health $(\mathrm{MCH})$ services. Adolescent girls, however, may be inadequately served by these antenatal and postpartum programmes given the elevated (combined social and clinical) risks of first births to the youngest mothers. ${ }^{38}$ Moreover, many of the services offered, such as contraception and sterilisation, are not sought by recently married young women. Even as the HIV epidemic moves into younger age groups, $\mathrm{MCH}$ programmes rarely make a special effort to reach the youngest first-time mothers. The cost of antiretrovirals to prevent mother-to-child transmission of HIV is declining, and a growing proportion of married women in developing countries are tested for HIV during antenatal visits or shortly before delivery. As with many maternal and child initiatives, however, the emphasis tends to be on protecting the child rather than on protecting both the child and mother. Such programmes often fail to fully recognise that keeping young, recently married girls, who are about to enter their peak childbearing years, HIV-free may be one of the best strategies not only for preventing the transmission of the disease to the next generation, but also for ensuring that these children are not orphaned.

\section{Common HIV/AIDS Protection Messages Are Often Inappropriate for Married Adolescents}

Also of plausibly limited value are the strategies targeted to unmarried sexually active adolescent girls in developing countries. Indeed, the authors' review of benchmark publications on adolescents and HIV found they implicitly or explicitly prioritise strategies for sexually active

\footnotetext{
${ }^{37}$ Mekbib, T.A., A. Erulkar, and F. Belete. 2004. "Who is being reached by youth programmes: Results of a capacity-building exercise," brief communication in Ethiopian Journal of Health and Development, in press. For more information contact Annabel Erulkar at aerulkar@pcaccra.org

${ }^{38}$ Miller, Suellen and Felicia Lester. 2003. "Re-orienting information, social support and services for the youngest mothers," paper presented at the WHO/UNFPA/Population Council Technical Consultation on Married Adolescents, WHO, Geneva, 9-12 December.
} 
unmarried youth in presumptively voluntary relationships in which pregnancy was not sought. Many publications and policies failed even to mention early marriage as a factor of interest, even though the conditions of early/child marriage meet the definition of "high risk." In the current debate over PEPFAR (the U.S. President's Emergency Plan for AIDS Relief), for example, Tom Flavin, a spokesperson for the Global AIDS Coordinator Office at the State Department, defined "high-risk" as "any situation in which a person was 'required' to have sexual intercourse with an individual whose HIV/AIDS status was unknown to him or her." 39 Sadly, evidence consistently shows that nearly all young brides fit this definition of "high-risk." Yet Flavin's additional assertion that "condom distribution for use in high-risk situations is very much part of the prevention strategy," suggests that he is not thinking primarily about protecting individuals in the "high-risk" situation of early marriage.

Thus, whereas the elements of married adolescents' social profile are given attention as potential components of being "at risk"-low educational levels, lack of social capital, social isolation, sex with older partners, required sex with an individual whose HIV status is unknown, economic dependence - early marriage itself has not been treated as a cross-cutting condition nor an area for policy work.

Currently recommended strategies for HIV/AIDS protection and risk reduction have been:

- to abstain from sexual activity;

- to reduce sexual frequency;

- to change sexual partners (to a safer partner);

- to use a condom (male or female); and

- to observe mutually monogamous relations with an uninfected partner.

Not one of these, save the last idealised situation (mutual monogamy with an uninfected partner), offers a feasible choice for newly married girls/women under pressure to become pregnant with more powerful and/or older husbands.

As early marriage has not been highlighted in the development of HIV/AIDS messages and no special efforts have been made to reach the newly married female, in many settings these girls are less likely to know a way to protect themselves from HIV (see Table 5). Indeed, some may even believe that they are protected by their marital status. ${ }^{40}$

\section{EXERCISES TO GUIDE COUNTRY-SPECIFIC ASSESSMENTS OF HIV RISKS ASSOCIATED WITH EARLY MARRIAGE}

In the latter part of this paper, we offer broad programmatic and policy recommendations that countries may adopt, depending on how they gauge the risk of HIV that may accompany early marriage. Herewith we suggest some analytic exercises to help determine the level of urgency in a given country and shape its response.

Four key analyses are suggested; note that preliminary tabulations are presented in Tables $1-5$ :

\footnotetext{
${ }^{39}$ Friedlin, Jennifer. 2004. "Scorecard on Bush finds rhetoric gap," WE News Correspondent, 8 March.

${ }^{40}$ Doumbia, Seydou and Martha Brady. 2002. Data from quantitative survey: Projet Promotion de la Jeunesse et des Sports du Mali: Éléments d'information sur la vie des adolescents de 13 à 16 ans dans la commune I du district de Bamako, Population Council. Tableau no 939: Pourcentage des adolescentes qui pensent que le mariage peut protéger contre le SIDA. New York: UNFPA, March; and Bracher, M., G. Santow, and S.C. Watkins. 2002. "Moving and marrying: Estimating the prevalence of HIV infection among newly-weds in Malawi," paper presented at the Population Association of America annual meeting, Atlanta, 9-11 May.
} 
- estimating levels and distribution of HIV/AIDS in the current population;

- determining prevalence of early marriage for the entire country and for specific subpopulations;

- determining the magnitude of the HIV risks accompanying early marriage; and

- assessing the availability of and access to programmes and services for married women, particularly younger or newly married women.

\section{Estimating Levels and Distribution of HIV/AIDS in the Current Population}

Estimating the age- and sex-specific prevalence, and, when possible, incidence of HIV among different populations is the first step in assessing what, if any, role early marriage or marriage per se will play in either stemming the tide of HIV or serving as its bridge to the general population. We do not delve into these statistics in this paper since most governments have been monitoring HIV prevalence, at least among the "high-risk" groups such as sex workers, migrant workers, and truck drivers. It is equally important, though often more difficult, to gather prevalence data from groups considered to be at low risk, like young, married, monogamous women. Their situation is indirectly and incompletely revealed by sentinel data drawn from antenatal clinics, which serve both married and unmarried pregnant women. These data often serve the function of estimating prevalence in the general population, but are flawed with respect to estimating prevalence among poor or unmarried women who are less likely to receive $\mathrm{MCH}$ care. Ideally, we would have survey and biomarker data from a random sample of young men and women who are followed longitudinally from age 15 to 30 . This information would be invaluable in determining the potential spread of the disease across the marital boundary and gauging the relative risks pre- and postmarriage.

The bridging role that married male behaviour plays in the epidemic is increasingly noted. For example, the East-West Center recently observed in its studies of the HIV/AIDS epidemic in Asia that:

There is an obvious link between HIV subepidemics in sex workers and their clients, the wives and girlfriends of the clients, and their children. Studies have shown, however, that transmission from husbands to wives occurs slowly. In several states of India, the average lag between the start of an HIV epidemic in sex workers and the rise of infection levels among pregnant women has been about five years (p. 2). ${ }^{41}$

This latter observation strikes a slightly positive note insofar as it suggests there may be time to prevent the epidemic from spreading to the general population by offering protection strategies to wives.

\section{Determining Prevalence of Early Marriage for the Entire Country and for Specific Subpopulations}

The prevalence of early marriage varies tremendously by country or within a given country among specific cultural or geographic settings. For example, while the nationwide median age at marriage is an important indicator, many countries have very low ages at marriage in some

\footnotetext{
${ }^{41}$ Brown. 2002. See note 33.
} 
specific parts of the country. (See Table 7 for areas where high proportions of girls aged 15 are already married, such as the Kayes region in Mali and the state of Bihar in India where rates reach nearly 40 percent and Amhara, Ethiopia, where rates are 50 percent)

Getting estimates of the pervasiveness of early marriage can be achieved by various measures, such as the median age at first marriage, the percentage married by age 15 or 18 , or if life table data are not available, simply the percentage of 15-19-year-olds who are married (see Tables 1 and 4). Although defining when early marriage is common enough to warrant special attention should be left to each country, the CRC and a variety of other covenants suggest that marriage before the age of 18 is effectively "child marriage."

\section{Determining the Magnitude of the HIV Risks Accompanying Early Marriage}

To determine the degree to which marriage marks an abrupt increase in HIV risk, two main measures should be considered: the percent of unprotected sexual activity occurring within marriage and the average age difference between young brides (i.e., those married under age 20) and their spouses.

Percent of unprotected sexual activity occurring within marriage compared to that occurring outside of marriage by age group

This measure is particularly salient for adolescent girls. Even if the overall percentage of girls married before the age of 18 is low, this group may still constitute a high percentage of girls at risk (i.e., girls having unprotected intercourse). Estimates of this ratio can be calculated as shown in Table 1. If, for example, more than a quarter of unprotected sex occurs within marriage, then the reproductive health needs of these married adolescents should be recognised and met along with the different needs of unmarried sexually active adolescents. The dramatic change in sexual behaviours that usually coincide with marriage, whether or not a girl is sexually active before marriage, can apply at any age or in any age group. Thus, this calculation is most useful among the age group that experiences the most transitions into marriage; in some countries this may not be ages 15-19, but rather ages 20-25.

\section{Mean age difference between married/unmarried adolescent girls and their partners}

Three aspects of age matter with respect to HIV risks and marriage: the age of the bride, the age of the groom, and the age difference between spouses. A girl's exact age at marriage, of course, needs to be considered as both her biological and emotional stage of development may affect her vulnerability to HIV. In addition, as discussed above, examining the age differential between partners may serve not only as a proxy for the relative power in the relationship, but also (after controlling for the age of the wife) as an estimate of the probability of infection among husbands. Average age differences of greater than three years or particularly large age gaps (i.e., more than 10 years) found among subpopulations would also indicate that husbands are more likely to be infected. When available, data on the average age difference of unmarried partners (girlfriends and their boyfriends) compared with the average age difference of wives and husbands in the same age group would offer an estimate of the expected differences in HIV probabilities in specific settings between husbands and boyfriends. 


\section{Assessing the Availability of and Access to Programmes and Services for Married Women, Particularly Younger or Newly Married Women}

Analyses should be undertaken by governments and NGOs to evaluate the reach of programmes that currently target or could target married adolescent girls. Regardless of whether such programmes prioritise HIV messages, any social, economic, or health programme that reaches married adolescent girls can be seen as a vital vehicle to stem the epidemic. The review to be undertaken should consider how organised efforts currently reach:

- about-to-be-married girls and their partners and parents;

- newly married girls and their partners;

- early married women and their partners; and

- first-time pregnant young women and their partners.

Relatively simple exercises may be undertaken to generate data on coverage. For example, a consortium of youth-serving organisations in Ethiopia recently tracked all contacts of peer educators over a six-week programme, and discovered very limited contact with married girls (about 22 percent of contacts, even in Amhara district where 80 percent of girls are married by age 18). ${ }^{42}$

Even without data on programme coverage, programme protocols and identification of research on which they are based (if any) should be reviewed to discern whether any distinction has been made between strategies for reaching (1) unmarried sexually active girls, (2) nulliparous or currently married pregnant girls, and (3) older, and presumably married, higherparity women. The lack of such differentiated planning may serve as a presumptive indicator of insufficient contact with married adolescents. As discussed above, programmes that are nominally open to both married and unmarried girls find that, without special efforts, they get very little participation from married girls.

A crude measure of the current ability to reach these groups is to compare stated knowledge about HIV and protection strategies of married adolescents to the responses of their unmarried, sexually active counterparts of the same age. As suggested in Table 5, this information could assess HIV knowledge, protection strategies, women's autonomy within marriage, ability to use condoms, desired delayed childbirth, and so forth. Again, we note that while these differences in information access or the applicability of protection strategies may be especially acute for married adolescent girls who are under pressure to have their first child and consolidate their marriages, and are relatively disempowered, they may also exist at older ages. Of special importance in HIV/AIDS policies and programmes are the messaging and communication strategies that accompany them. Have the messages been especially tailored to the newly married? Are there clear plans for how to reach this group, given their relative social isolation?

On the positive side, some countries may have exceptional systems of contact with the engaged, marrying, and young married populations. If such procedures and service infrastructures exist, these may afford convenient, culturally acceptable points of contact and intervention.

\footnotetext{
${ }^{42}$ Data are for 20-24-year-olds. Source: Central Statistical Authority and ORC Macro. 2001. See note 20.
} 


\section{COUNTRY PROFILES IN BRIEF}

While it is beyond the scope of this paper to identify the specific needs for all countries based on their marriage and HIV profiles, we present four illustrative and contrasting scenarios to suggest how the factors presented in Tables 1-5 and the analyses proposed in the previous section may be used to weight the importance of reaching young women with realistic HIV messages as they approach and cross the marital boundary. That said, each country (and possibly at the subnational, regional level) must assess its own needs and tailor a response to suit the context. We have refrained from offering policy advice in the context of case studies in this section and have saved such propositions for the end.

\section{Burkina Faso}

Burkina Faso has low, but increasing, HIV rates in high-risk subpopulations. The prevalence rate is substantially higher among young women aged 15-24 (with estimates ranging from 7.8 percent to 11.7 percent) than among young men (3.2-4.8 percent). The prevalence rate among sex workers in major urban settings is approximately 60 percent, while women in urban antenatal clinics have a rate of under 8 percent.

Marriage profoundly shapes the sexual behaviours of girls, given that approximately twothirds of women aged 20-24 were married by age 18. Indeed, the contrasts between married and unmarried girls are strong in Burkina Faso, perhaps stronger than in many settings. Married girls are much more likely to have had unprotected sex; indeed, married girls are 12 times more likely to report having had unprotected sex in the last week than are unmarried girls (Table 1, Column 8 [i.e., Column 5 divided by Column 6]). Even compared to sexually active unmarried girls, the relative risk of married girls having had unprotected sex last week is still 2.6 times higher, which is attributable both to the increased frequency of sex and to the decreased use of condoms. Pressure to become pregnant shortly after marriage is also evident: 61 percent of nulliparous married girls desire pregnancy in the next two years, and the mean interval between marriage and first birth in this age group is 19.0 months (Tables 2 and 4). Yet even among girls who do not wish to become pregnant, almost a fifth of married girls reported having unprotected sex last week compared to 1 percent of unmarried girls (Table 3, Columns 4 and 5). Most strikingly, the mean age difference between spouses is nearly 12 years (Table 4, Column 6), suggesting that husbands are likely to have considerably more sexual exposure than their wives prior to marriage and are more likely to be infected. Given this profile, we could classify Burkina Faso as a country where early marriage for girls may be a particularly vulnerable point of entry for HIV into the general population.

\section{Zambia}

Early marriage has often not been perceived as a risk factor in southern Africa largely because South Africa, the largest country in the southern region, has a relatively late age at first marriage and sexual experience outside of marriage is common. Compared to the other 30 countries presented in Table 1, South Africa is a clear outlier with only 7.3 percent of sexually active adolescent girls being married. Yet, in other countries in southern Africa, such as Mozambique, Zambia, and Zimbabwe, sex for adolescent girls frequently occurs within marriage (the percentage sexually active who are married ranges from 44 percent to 69 percent). Thus, while South Africa represents one of the only countries where our analyses indicate that early marriage 
is not a common context for HIV infection, in the rest of southern Africa where HIV/AIDS epidemics are well underway, early marriage may be an important contributing factor.

In Zambia, low estimates of HIV prevalence rates indicate that 10 percent of men aged 15-24 and 26 percent of women aged 15-24 are infected. For women, this estimate can reach as high as 40 percent. Early marriage is common in Zambia with 52 percent of girls marrying by age 18 . Perhaps more unique to Zambia is that less than half (44 percent) of sexually active adolescent girls are married, suggesting relatively high rates of premarital sexual activity. Strikingly, however, married adolescents represent a clear majority of those who reported having unprotected sex in the last week ( 82 percent), due mainly to a greater frequency of sex within the marital relationship rather than a decrease in condom use. Over 40 percent of women (Table 5, Column 9) felt it was justifiable for a husband to beat his wife if she refused to have sex.

Interestingly, these pronounced differences in current behaviours and reported behavioural changes persist despite the large proportion (28 percent) of currently unmarried girls seeking pregnancy in the next two years. On average, husbands of girls married before age 20 are 6.7 years older than their wives.

While Zambia has promoted several large youth outreach and family life education programmes, these programmes, by and large, do not reach the sizeable proportion of adolescent girls who are married. Thus Zambia represents countries where the need to implement special efforts to reach married adolescents with protection strategies is especially pressing and where ignoring the risks to married women may undermine its existing HIV intervention programmes.

\section{Dominican Republic}

The Dominican Republic can also be characterised as having low but rising HIV rates especially among specific groups. With 2.5 percent of the population living with the virus, the Dominican Republic already has one of the highest HIV prevalence rates in the Latin America and Caribbean region, though these estimates are currently low compared to parts of Africa.

More than 35 percent of women marry before the minimum legal age of marriage of 18. Yet, unlike in many other settings, these early marriages appear to be largely motivated by the adolescent's desire rather than parental preferences. In the Dominican Republic, informal consensual unions, called marriages "without papers," are more common than legal, formal civil or religious marriages. ${ }^{43}$ Indeed, informal marriage is most common among adolescent girls, comprising over 92 percent of their unions. Relative to formal marriages, these marriages without papers tend to be more precarious as the high proportion of already separated or divorced girls aged 15-19 attests. Moreover, these informal marriages do not confer the same legal rights or benefits as legal marriages upon separation, divorce, or widowhood. The implications of these informal marriages for adolescent girls with respect to HIV risks have yet to be thoroughly explored. Yet, high dissolution rates and low economic standing may contribute to a relatively high rate of serial monogamy reported by young women in the Dominican Republic.

Indeed, for adolescent girls these consensual unions and marriages are by far the most common route to sexual relations in the Dominican Republic. Although over a quarter of girls aged 15-19 are sexually active, nearly 80 percent of these girls are married. Only 7 percent of never-married girls nationwide report having ever had sexual intercourse. In addition, married

\footnotetext{
${ }^{43}$ Castro Martin, Teresa. 2002. "Consensual unions in Latin America: Persistence of a dual nuptiality system," Journal of Comparative Family Studies 33(1): 35-55.
} 
adolescent girls have much lower rates of condom use than their unmarried counterparts. For example, among sexually active girls 15-19 years old, 30 percent of those never married report condom use at last sex, compared with 3 percent of married girls. As a result fully 96 percent of unprotected sexual encounters in the last week among adolescent girls occurred within marriage (Table 1). Desire to become pregnant partially explains these differences in levels of unprotected sexual exposure. Among nulliparous women, 30 percent of married girls compared to only 13 percent of unmarried girls desire a pregnancy in the next two years. The mean interval between marriage and first birth is 20 months.

Among currently married 15-19-year-old girls, the mean age difference between partners is 7.2 years. By virtue of their age, older partners are likely to have had previous sexual partners; indeed, the nationwide median age at first sex for males is 16.6 years, while their median age at first marriage is 24.6 years, leaving a long interval for premarital relationships. In contrast the median age at first sex for females is 18 , while the median age at first marriage is about half a year later at 18.6.

Married adolescent girls are more socially isolated than their unmarried peers. Although over 90 percent of unmarried girls aged 15-19 are currently in school in the Dominican Republic, three out of five married girls are neither in school nor working (Table 5). Even when there are no children to care for, marriage still limits school attendance. Unmarried girls aged 15-19 without children are nearly three times more likely than married girls without children to be in school. Qualitative research has also revealed that married adolescent girls are less likely to participate in community groups than either their unmarried counterparts or older married women. ${ }^{44}$ Thus, although the overall prevalence of HIV is low by international standards, the high frequency of unprotected sex occurring within marriage and substantial difference in spouses' ages, coupled with the social isolation of married adolescent girls, makes them a particularly important group to monitor and safeguard in the Dominican Republic. ${ }^{45}$

\section{India}

India exemplifies the importance of evaluating the characteristics of each country (and sometimes even regions within a country). Like the Dominican Republic the current prevalence of HIV is relatively low, with less than 1 percent of the population infected (although rates are already twice as high in women as in men). There is widespread concern, however, that the disease is poised to spread from concentrated groups to the general population. Unmarried girls' behaviours are closely monitored and premarital sexual experience for girls is strongly discouraged. The age at marriage for girls is quite low and early marriage continues to be common with over 60 percent of women married by age 18. Marriage, consequently, is the main route to unprotected intercourse. However, compared to most other countries with similar marital profiles, husbands are on average only a few years older than wives.

Measuring the relative magnitude and vulnerability of married adolescents in these settings is often difficult, because the comparison group, unmarried sexually active adolescents, is often missing from the data and/or comprise such small numbers as to render comparisons unreliable (unmarried girls are not interviewed in the NFHS-1 or NFHS-2). Precisely because unmarried girls are expected to refrain from sexual activity, however, we can infer that the transition to

\footnotetext{
${ }^{44}$ Goldberg, Rachel. 2003. "Structures of risk: Gender and HIV/AIDS in the Dominican Republic," master's thesis, Columbia University Mailman School of Public Health.

${ }^{45}$ Goldberg. 2003. See note 44.
} 
marriage and the coinciding HIV risks are especially stark. Indeed, it has been reported that at most 10 percent of girls are sexually active before marriage, indicating that married girls comprise well above 85 percent of sexually active girls and more than 95 percent of girls who had unprotected sex last week. ${ }^{46}$

Marriage also marks a transition to greater social isolation for many women in India. Upon marriage girls often leave their natal homes and frequently move in with their husbands' families who may reside in another town or village. ${ }^{47}$ Married adolescent girls in India also have very little knowledge of HIV with only 30 percent having ever heard of HIV. Pressure to bear children, especially sons, soon after marriage may be particularly acute.

The age gap between husbands and young brides in India (6.3 years) is smaller than in Burkina Faso. Nonetheless, on average, this age difference is larger than the average spousal age difference of older brides (women who marry after 20), which is 5.0 years. While conclusive data are lacking, about 20-25 percent of unmarried school- and college-aged boys reported engaging in premarital sex — often with a sex worker. ${ }^{48}$ Since some, but certainly not all, young men will come to marriage sexually experienced this additional 1.3-year age difference may make an important difference in HIV rates among husbands of young brides.

The assumption that married women are at little if any risk of HIV has led to an alarming discrepancy between married women's real risk and their perception of risk. Two studies report extremely limited knowledge or perception of risk for HIV among married, monogamous, HIVpositive women in Mumbai. ${ }^{49}$ While the first wave of HIV cases has already begun to hit highrisk populations such as sex workers in Mumbai, there are warning signs that the second wave will be among married women and that these women are ill-prepared to protect themselves and their children. New studies are urgently needed to design appropriate policies. For example, in cities or states where the HIV epidemic is underway, we need longitudinal studies that collect information about sexual activity, knowledge regarding HIV, and, ideally, biomarkers of HIV status for young women and men as they cross the marital boundary. A better understanding of the risks of young men and women both inside and outside of marriage is vital to developing appropriate policies.

\section{POLICY OPTIONS}

So far we have presented evidence suggesting that under certain circumstances marriage may not represent a safety zone for girls and young women with respect to HIV. We have also identified four key summary measures to give guidance for when marriage, especially early marriage, might represent an important threshold for increasing HIV risks. In this next discussion, we explore the policy options and decisionmaking points.

\footnotetext{
${ }^{46}$ Santhya, K.G. and Shireen Jejeebhoy. 2003. "Sexual and reproductive health needs of married adolescent girls," Economic and Political Weekly 38(41): 11 October.

${ }^{47}$ Elul, Batya. 2003. "Induced abortion in Rajasthan, India: Prevalence estimates from two quantitative methodologies," personal communication from a working paper.

${ }^{48}$ Santhya and Jejeebhoy. 2003. See note 46.

${ }^{49}$ Gangakhedkar, R.R., M.E. Bentley, A.D. Divekar, D. Gadkari, S.M. Mehendale, M.E. Shepherd, R.C. Bollinger, and T.C. Quinn. 1997. "Spread of HIV infection in married monogamous women in India," Journal of the American Medical Association 278(23): 2090-2092; and Newmann, S., P. Sarin, N. Kumarasamy, E. Amalraj, M. Rogers, P. Madhivanan, T. Flanigan, S. Cu-Uvin, S. McGarvey, K. Mayer, and S. Solomon. 2000. "Marriage, monogamy and HIV: A profile of HIV-infected women in south India," International Journal of STD \& AIDS 11(4): 250-253.
} 


\section{Political Leadership}

Before turning to a more systematic review of some of these, we highlight the important role that leadership at the top must play in successful efforts to combat HIV transmission within marriage. Thus a key policy decision that leaders need to make is whether delaying marriage to at least age 18 and calling attention to the risks of HIV transmission within marriage will be explicit elements in the HIV-prevention policy.

The most recent prime minister of Mozambique, Pascoal Mocumbi, was one of the first national leaders to put forward a position on this question; he defined later and chosen marriage as both a human right and an HIV-protection strategy and noted the "confusions" in parents' minds regarding the safety that marriage offers to daughters. In an editorial in The New York Times he cited the high HIV rates among young women and stated, "Parents know little about sexuality, contraception, or sexually transmitted diseases, and many believe that early marriage will 'protect' their daughters." ${ }^{50}$ Most recently, Nigeria joined the ranks of countries raising the age of marriage to 18-with the explicit support of the highest-ranking Islamic cleric in Northern Nigeria, the Saudana of Sokoto. ${ }^{51}$ Although many different threads were interwoven in the campaign for higher age of marriage, a concern about HIV played a role as a link was made between girls' school drop-out, early marriage, and HIV. ${ }^{52}$ Another example, with more explicit links and one that has received very little notice, was the statement by former President Daniel Arap Moi of Kenya in 1999, raising the legal age of marriage from 14 to 18, citing the HIV epidemic as a key factor. ${ }^{53}$

Provided there is political will, specific policy measures for mitigating the risks of contracting and spreading HIV via marriage can be identified and implemented. Below we have provided an initial framework to guide country or subnational decisionmakers and advocates. For the purpose of the exposition, we have organised these policy options in chronological order from premarriage to post-first birth. The order does not, however, represent a ranking of importance, and we are certain it does not cover the full range of options.

\section{Premarriage Options}

\section{Evaluating the legal basis for eliminating underage/child marriages}

In most countries, minimum ages of marriage were established as part of a charter of rights in a society to define "adult" or majority status, and to offer protections to young men and women and boys and girls (see Table 4, Column 1, for minimum legal age at marriage). In that spirit, countries need to review the logic and justice of their laws, their cultural interpretation, levels of compliance, and the implications for HIV risk if these laws are violated. A first task is the alignment of national policies with the Convention on the Rights of the Child; the CRC effectively establishes marriages before 18 as "under age" or "early marriage" —in effect, child marriage. Most, but not all, countries are in compliance with this emerging international standard. In some countries, this has meant equalising the ages for males and females since, in

\footnotetext{
${ }^{50}$ Mocumbi, Pascoal. 2001. "A time for frankness on AIDS and Africa,” New York Times, 20 June, p. A23.

${ }^{51}$ Generation 2000: Changing Girls' Realities. Fonda Inc. and the International Women's Health Coalition, 2000.

${ }^{52}$ Dorothy Aken'ova, personal communication, 2003; Corinne Whitaker, personal communication, 2004.

53 Judith Achieng'. 1999. "Minimum consent age raised to curb spread of AIDS," Inter Press Service, 29 November.
} 
some countries, the age of legal marriage for males was considerably higher than that for females.

In some settings, assuring the legal basis for deferring marriage to age 18 or beyond requires confronting competing parental rights. In some settings, girls as young as age 12 can be married with "parental consent." The construction of such laws, of course, assumes the situation of young people seeking marriage against their parents' will. What is far more likely is parents' exercising absolute control over their children's, principally their daughters', lives by forcing early marriage, nominally for economic or cultural reasons, such as protecting the family's reputation.

At the recent Child Summit (2002), there was a debate over parental rights - often connected to concern over adolescents' independence and their reproductive rights. This debate has given limited attention to arranged child marriages. There may be clear conflicts over whether parents' arranging a marriage is their right or a violation of girls' and boys' rights. The Declaration of Universal Human Rights and the CRC clearly give the young person the right to consent in marriage and suggest, if the CRC age benchmark is accepted, that such consent cannot be given until age 18.

\section{Developing community-based initiatives that redefine acceptable ages of marriage and offer incentives to parents and girls to delay marriage to legal age}

While there is an understanding of the broad determinants of delayed marriage, and some programmes appear to have made a contribution in that direction, experiments explicitly designed to delay marriage are very few. Considerable attention has been given to the role that education plays in delaying marriage; this role is not formal and direct as mandated schooling often ends long before the time when marriages begin. However, it appears that girls with more formal schooling continue to be married at a later age than girls with lesser or no schooling. The school/delayed marriage link is part of a broader scheme of social and economic change that makes it more likely girls will exercise choice in marriage as delayed marriage is more economically sustainable. ${ }^{54}$

The relationship between work and delayed marriage has received less attention, but there is some evidence that girls who work for wages tend to marry later. Indeed in some communities, the very prospect of working for wages (which requires some higher level of schooling) may itself play a role in deferring marriage. ${ }^{55}$ Some community-based social development initiatives also appear to have spin-offs regarding age at marriage. Recently, the Centre for Development and Population Activities (CEDPA) reported that its Better Life Options Program in India appeared to contribute to a later age at marriage, although CEDPA calls for more research on the exact mechanisms and the degree of change that can be attributed to the program. ${ }^{56}$

One of the most purposeful community-based efforts to delay marriage that we could identify was that of Maqattam - a project in the garbage-collecting districts of Cairo, Egypt. The organisers of this several-decades-old programme discovered that underage marriages (under age

\footnotetext{
${ }^{54}$ Mensch, Barbara S., Susheela Singh, and John Casterline. 2003. "Trends in the timing of first marriage among men and women in the developing world," draft, 12 June, submitted to Population Association of America 2004; and Bruce, Judith, Barbara S. Mensch, and Margaret E. Greene. 1998. The Uncharted Passage: Girls' Adolescence in the Developing World. New York: Population Council.

${ }^{55}$ Amin, Sajeda, Ian Diamond, Ruchira Tinaved, and Margaret Nubi. 1998. "Transition to adulthood of female factory workers in Bangladesh," Studies in Family Planning 29(2): 185-200.

${ }^{56}$ Centre for Development and Population Activities (CEDPA). 2001. Adolescent Girls in India Choose a Better Future: An Impact Assessment. Washington, DC: CEDPA.
} 
16- the Egyptian law at the time) persisted even in the context of social, economic, and environmental programmes that involve substantial numbers of girls in functional literacy, income generation, and social development activities. Puzzled by the number of girls still married at early ages, the sponsors of the Maqattam project established a Crisis Committee, which often engaged in negotiating between family members in disputes. Such disputes included girls' appeals to the committee regarding pressure, sometimes outright coercion, to marry young and to marry a suitor undesirable to them. There were cases of girls presenting themselves with cuts on their wrists, and one told the story of trying to jump off her roof after being apprised of her family's plans. The Crisis Committee decided to change the terms of reference around early marriage in the community by offering 500 Egyptian pounds (about US\$150) to any girl who, upon her marriage, could prove that she was past her eighteenth birthday and that the marriage was voluntary. Working within a community setting where degrees of voluntarism and age compliance could be discerned worked well. This programme has been in operation for the last 10 years. Since 1995, when the programme was established, a key organiser, Marie Assaad, reports that no girls are known to have been married before age 18. Some 112 girls have been explicit beneficiaries of the programme. ${ }^{57}$

Given the dearth of examples of community-based efforts to promote later marriage, we may look to the literature on efforts to reduce the extensiveness and degree of female genital cutting (FGC). Though many countries in which FGC is widely practiced have prohibited it for decades, these laws were unenforced and often unknown. Further, FGC - like early marriage - has often been portrayed, even defended, as an integral part of local culture. The confluence of the international human rights movement, economic and social changes, growing recognition of women as citizens, and systematic documentation of the damage and death caused by FGC led to the development of community-based efforts. These efforts typically combine accurate information dissemination; social mobilisation of parents, elders, and other leaders in the community; retraining of practitioners of genital cutting; and - in some instances - legal action against purveyors of FGC or parents (such as recent cases in Tanzania and Ghana). ${ }^{58}$

New initiatives to make marriage safer may build directly on existing FGC mobilisation structures. For example, in Senegal, through the help of Tostan, an international, nongovernmental organisation, over 800 communities have already made the declaration to end FGC and, "in the coming months, hundreds of Bambara, Fulani and Diola Fogni communities ... will also pledge an end to FGC and early marriage to improve the health of girls and women [emphasis added]."59

While these examples are certainly at the edges of collective social action and innovation, if and when early marriage is recognised as a human security crisis that undermines more important community values and is linked to HIV, it is not impossible that communities will be similarly motivated to take extraordinary measures to protect themselves. Though we will likely

\footnotetext{
${ }^{57}$ Marie Assaad, personal communication; and Assaad, Marie and Judith Bruce. 1997. "Empowering the next generation: Girls of the Maqattam garbage settlement," SEEDS no. 19. New York: Population Council.

${ }_{58}$ Mohamud, Asha, Samson Radeny, Nancy Yinger, Zipporah Kittony, and Karin Ringheim. 2002. "Protecting and empowering girls: Confronting the roots of female genital cutting in Kenya," in Nicole Haberland and Diana Measham (eds.), Responding to Cairo: Case Studies of Changing Practice in Reproductive Health and Family Planning. New York: Population Council, pp. 434-458; Ismailly, Jumbe. 2003. "Three get 30 years after FGM victim dies," http://www.ippmedia.com, 11 October; and Ghana News Agency. 2003. "Woman gets five-year jail term for performing FGM," http://www.ghanaweb.com, 24 September.

${ }^{59}$ Tostan News. 2003. "108 villages publicly declare the abandonment of FGC and early marriage in Salemata on March 30, 2003," http://www.tostan.org, 30 March.
} 
be unable to effectively or acceptably deal with early marriage unless there is community-level mobilisation, at some point national governments will have to be ready to defend young women against abuses of their rights and, in turn, hold accountable through legal measures those who promote or force early marriage upon children. ${ }^{60}$

\section{Raising public awareness that marriage is not necessarily a safe place}

Increasing the public's willingness to raise the age of marriage — past the eighteenth birthdaymay require directly countering the common myth that early marriage will shelter adolescent girls from risks, particularly sexual risks. Small, qualitative studies in Mali have found that a surprising proportion of girls — almost 30 percent overall — either believe that marriage protects them from HIV or "don't know." ${ }^{, 61}$ In qualitative interviews in Malawi, parents often mention their desire to marry their girls off early to protect them from the dangers of HIV. ${ }^{62}$

The connections between early marriage and HIV risks must be made explicit and publicised by political leaders and through the media. As with efforts to reduce FGC, messages about the HIV risks associated with early marriage will need to move into the public sphere. A step in this direction was a recently taken in the Dominican Republic where an educational film called Daniela, which portrays the true story of a 17-year-old girl who was infected with HIV by her husband, was widely distributed throughout the country. Other media efforts in different contexts need to emphasise parents' complicity in putting their children at risk by encouraging or even forcing some marriages. A short film, produced as part of Scenarios of the Sahel, a media project to make HIV/AIDS messages accessible, featured a story of a young girl who was married by her greedy father to an older man. ${ }^{63}$ While her father received a gold wristwatch, the results for the girl were a better home and the acquisition of HIV. The final scene of the film shows the girl returning to her home, heartbroken while explaining to her father that both she and her new baby are HIV-positive. Throughout the film, the father is assailed by his conscience. The clear message is that parents must not sell the health and rights of their children.

A recent study of the determinants of condom use among young people in urban Cameroon can provide some guidance on how to make messages of HIV protection, including condom use, salient to resistant and young populations. While this analysis was not directed at the behaviour of young, married adolescents, it did consider the dilemma of young people in regular sexual partnerships. The authors suggest that "youth-oriented programs seeking to increase the number of new condom users among the young should promote parental support for condom use and enhance young people's perceptions of personal risk. Programs that work to convince the young that their sexual history can put them at risk of HIV infection and that dispel the myth that HIV risk with regular partners is low may serve to increase personal risk perception [emphasis added]" (p. 335). ${ }^{64}$ The authors also suggest that young people's — most particularly girls'perceptions of their parents' attitudes toward condom use may be an important determinant of

\footnotetext{
${ }^{60}$ In Kenya, the African Inland Church Girls Primary School provides quality education and shelter to young girls who have been "rescued" from early marriages. Source: "FAWE: Centering on excellence," Carnegie Reporter 1(3): Fall 2001, http://carnegie.org/reporter/03/eduafrica/fawe.html.

${ }^{61}$ Doumbia and Brady. 2002. See note 40.

${ }^{62}$ Bracher, Santow, and Watkins. 2002. See note 40.

${ }^{63}$ Nacro, Fanta Régina. 2001. "The voice of reason," from the media project Scenarios of the Sahel. Ouagadougou: Global Dialogues.

${ }^{64}$ Meekers, Dominique, and Megan Klein. 2002. "Determinants of condom use among young people in urban Cameroon," Studies in Family Planning 33(4): 335-346.
} 
their behaviour. There may be an analogous potential in creating parental support for delayed marriages through, among other things, increasing parents' awareness of the HIV, human rights, and developmental risks of early marriage.

\section{Emphasising the importance of safe, age-appropriate spouses}

While HIV cannot be diagnosed by an individual's appearance, that does not mean that certain characteristics are not associated with greater probability of infection. Parents and adolescent girls need to be aware of the correlations among age of suitors, their previous sexual experience, and likelihood of HIV infection. Since the probability of being infected rises monotonically with age, younger men, those closer to their potential wives in age, should be considered safer and, subsequently, more desirable. One of the most important factors increasing the age at marriage for men is the need to secure enough resources to pay an often substantial brideprice. Policies designed to minimise or eliminate the practice of brideprice or other economic exchanges at the time of marriage may help to diminish age differences between spouses. The first-ever international conference on brideprice was held in Kampala, Uganda in February 2004. Frank discussions took place on the links between poverty, brideprice, age and agency of the bride, the risk of subsequent violence against her, and the characteristics of the spouse, including the age difference between the bride and her husband. ${ }^{65}$

Cultural norms supporting the notion of the sexually experienced husband may also promote unsafe spouses. While in many settings, females are expected to be virgins at the time of marriage, the reverse is usually true for males. Such diametrically opposed cultural norms and double standards need to be addressed head-on. In many if not most cultures an "abstinence before marriage" policy message targeted toward adolescent girls will have little additional impact as this message is usually already clearly transmitted via other channels. In contrast, this message sent to adolescent boys and male youth would be nothing short of a countercultural revolution in sexual expectations and norms in many societies. Indeed, it may be so countercultural as to be impractical. Yet, fostering norms that value virgin grooms (defined as having had no penetrative sexual relations with either sex) as highly as virgin brides could substantially increase the pool of safe (uninfected) husbands for girls and the safety of marriage for both males and females. Such prescriptions need careful, context-specific review as the promotion of virginity for either sex could quickly become doctrinaire, abstinence-only messages (which, unqualified, could undermine messages about protected sexual relations and condom use).

\footnotetext{
${ }^{65}$ For more information on this international conference organised by Mifumi, which took place in Kampala, Uganda, 16-18 February 2004, write Naana Otoo-Oyortey at International Planned Parenthood Federation, London, at notoooyortey@ippf.org. Patrick Ndira, at patrickndira@mifumi.org, is the advocacy officer for the Mifumi project based in Uganda.
} 
Weighing whether later marriage will plausibly expand the number of unmarried, sexually active, and at-risk adolescents

The reluctance to promote later marriage as part of HIV prevention may be founded on a widespread belief that later marriage increases the number of unmarried, sexually active adolescents, a concern that is primarily applied to adolescent girls. Above we have provided reasons to challenge the common image of the irresponsible, dangerous, sexually active, unmarried adolescent contrasted with presumably safe, mutually monogamous sexual relations within marriage. In addition, we contend that there is little evidence to support the fear that adolescent girls who delay marriage and, therefore, sexual initiation through marriage will instead initiate sex outside of marriage. Arguably the rate at which girls are likely to remain virgins or engage in premarital sex as the age of marriage increases is a function of the age at marriage. Raising the median age of marriage from 16 to 18 would have a different effect than raising it from 18 to 21 .

Putting aside concerns about girls' human rights and development goals, raising the age at marriage may not necessarily result in a larger pool of sexually active unmarried girls. A recent review of 120 surveys conducted since 1990 in 71 countries as part of the Demographic and Health Surveys programme, noted that, "Among 30 developing countries with more than one survey since 1990, levels of adolescent premarital sexual experience remained about the same [emphasis added]" (p. 27) ${ }^{66}$ Yet, while the proportions of young girls reporting premarital sexual experiences were relatively constant, among the 15 countries in sub-Saharan Africa with two or more surveys during this time period, the median age at first marriage increased by about 4 months. Indeed, researchers looking for explanations of the decline in HIV prevalence in Uganda have suggested that it may be attributable mainly to changes in sexual behaviours, especially delayed sexual debut, and increased condom use among youths. The authors further note that this delay in sexual initiation was accompanied, and we might argue partly driven, by a delay in the age at marriage. Indeed, over the period of the most rapid decline in HIV rates, 1989-95, the proportion of ever-married girls aged 15-19 declined from 54 percent to 38 percent. ${ }^{67}$

\section{The Marriage Transition}

In many cultures, marriage is a process rather than a discrete event. ${ }^{68}$ Indeed, the formal marital boundary in some societies is not the important one, but rather there is a parallel social processrituals, customs, and so forth - that demarks marriage eligibility and active pregnancy-seeking. This social process (premarriage ceremonies, celebrations, customs, and registrations) may provide a series of entry points for promoting information about couple communication,

\footnotetext{
${ }^{66}$ Zildar, V.M., R. Gardner, S.O. Rutstein, L. Morris, H. Goldberg, and K. Johnson. 2003. "New survey findings: The reproductive revolution continues," Population Reports series M, no. 17, Spring. Baltimore: Johns Hopkins University Bloomberg School of Public Health, The Info Project.

${ }^{67}$ Asiimwe-Orkiror, Godwil, Alex Opio, Joshua Musinguzi, Elizabeth Madraa, George Tembo, and Michel Caraël. 1997. "Change in sexual behaviour and decline in HIV infection among young pregnant women in urban Uganda," AIDS 11(14): 1757-1763.

${ }^{68}$ Bledsoe, Caroline H. and Barney Cohen (eds.). 1993. "Marriage: New forms, new ambiguities," in Social Dynamics of Adolescent Fertility in Sub-Saharan Africa. Washington, DC: National Academies Press, pp. 37-68; and Bledsoe, Caroline and Gilles Pison (eds.). 1997. Nuptiality in Sub-Saharan Africa: Contemporary Anthropological and Demographic Perspectives. Oxford: Clarendon Press.
} 
counseling and testing, condoms, sexual health, safer marriage, and childbearing - including ensuring healthy, disease-free children - to newly engaged couples.

Drawing on the sacred associations of marriage to communicate about protection against HIV

Successful communication strategies currently geared toward unmarried adolescents to improve discussions about sexual matters between parents and their children could be adopted to encourage communication between spouses. To illustrate this potential, we draw on a widely circulated newsletter in Zambia sponsored by FHI/YouthNet called Trendsetters. According to its Web site, "Trendsetters fosters an atmosphere in which young people can discuss sex-related issues with parents, guardians, and other family members. " ${ }^{69}$ Interestingly, husbands are not mentioned specifically as key family members, even though for 45 percent of sexually active girls and 82 percent of adolescent girls who had unprotected sex last week, husbands undoubtedly played the most decisive role in making decisions about sex-related issues.

The messaging opportunity at the marital boundary is complex. While in many cultural traditions sexuality is seen as discussable — even positive - in the context of marriage, marriage is also presumed to offer safety and fidelity, thus discussing risks within marriage may seem unnecessary or disrespectful. The marital boundary is a point at which many young women - and their partners - formally consider the architecture of their future reproductive and family lives, bolstered by the sacred and the traditional. A set of ideas may be developed that honors marriage while bringing forward real and important understandings about risk and trust. The almost universal attachment to children - as proof of fertility (especially the first child), as consolidation of a marriage, and as a symbol of family continuity - may allow for conversations on highly sensitive subjects.

Emphases on mutuality, voluntarism, and pleasure in marital sexual relations could open up the door to discussions of safety in marital sex. Some religions and cultural traditions legitimise the expectation of pleasure in marital sexual relations - for men and for women. Indeed, young brides in Senegal mentioned one of the most positive changes in marriage was the physical pleasure and intimacy with their husbands. ${ }^{70}$ Such pleasure or intimacy cannot be achieved in the presence of fear of disease or safety. Thus, the sacred bond of sexuality in marriage could be interpreted to include the idea that wives and husbands have not only the right, but also plausibly the obligation, to resist unsafe and unwanted sexual relations.

\section{Offering voluntary counseling and testing at the time of marriage}

Where there are highly effective marriage registration systems or other publicly marked premarital or marital celebrations, it may be relatively less costly to use these venues as primary vehicles through which to provide voluntary counseling and testing (VCT) for HIV. Encouraging couples to undergo VCT requires fostering a high degree of communication and trust between partners and a plan to deal with the results, whether positive or negative for each partner.

\footnotetext{
${ }^{69}$ Phiri, Mary. "TRENDSETTERS, Zambia: Teens produce newspaper to encourage healthy behaviors," http://www.fhi.org/en/Youth/YouthNet/Publications/FOCUS/ProjectHighlights/trendsetterszambia.htm, accessed 25 August 2004.

${ }^{70}$ Diop and N'Dione. 2002. See note 25.
} 
Screening for other diseases that could affect children, such as Down syndrome and haemophilia are often seen as acceptable at the time of marriage. Additional tests for STIs and particularly HIV may also be viewed as appropriate at the time of marriage. Although many complexities on the subjects of voluntarism and stigma remain whenever VCT promotion is directed at one particular group, there is some legitimacy and apparently elevated interest in VCT on the part of the about-to-be-married at least in Uganda. A study there reported that "young women who desire to get tested tended to do so if they were about to be married, enjoyed their partners' support, and knew their partners would be willing to pay for support. Nearly two of every three girls said their partners encouraged them to be tested."71 VCT may even be creatively included in cultural practices around marriage such as, for example, in India where couples' astrological charts are matched to see if they are compatible. Perhaps the concept of compatibility could be extended to HIV status - the notion being that couples need to have this knowledge, share it with each other, and, if there is an incompatibility, seek additional counseling about protective practices.

\section{Redefining the First Year of Marriage as a Health Zone}

It may be worthwhile to characterise the first year of marriage as a "health zone" on the part of public health professionals. In the context of a new marriage and the prospect of future children, assuring the safety of both mother and child can become weighty arguments for behaviour change. ${ }^{72}$ Yet individuals adopting innovative behaviour in isolation are often penalised. Increasingly, communication for behaviour change is framed as communication for social change-recognising the relative powerlessness of individuals on their own to alter risky, yet socially promoted, behaviours. Many of the protective social messages, behaviours, fertility, and health patterns described below will only be feasible if there is concerted social support and explicit efforts to reduce the personal costs of behavioural change to the individual and include him or her in a broader social movement for change.

\section{Fostering more intimate and trusting relationships between new spouses}

The youngest brides and their partners are often not only socially isolated from their peersespecially in the case of the bride - but also embedded in larger family structures. As this challenge is context-specific, some analysis needs to be done of how best to support the couple's own bond with each other.

In settings where polygamy is widespread and/or spousal age difference is large, there will be a significant challenge in determining the best strategies to reach perhaps two distinct types of couples - young brides with much older spouses and young brides with spouses closer to their own age.

In the Asian subcontinent among comparably aged brides and grooms who often immediately join an extended family after marriage, there is often a strong desire on the part of the couple to get to know each other better. In such circumstances, workshops and follow-up sessions for just

\footnotetext{
${ }^{71}$ Juma, M., A. McCauley, E. Kirumira et al. 2002. "Gender variations and uptake of VCT services among youth in Uganda," presentation at XIV International Conference on HIV/AIDS, Barcelona, 7-12 July.

${ }^{72}$ Zulu, Eliya Msiyaphazi, Susan Cotts Watkins, and Gloria Chepngeno. 2002. "Spousal perceptions, comprehension and management of HIV/AIDS risk in rural Malawi," presentation at University of Pennsylvania Conference on HIV in Malawi, October.
} 
the couple have been organised to great effect. ${ }^{73}$ Research on the youngest first-time parents reveals a desire on both sides for greater intimacy and information exchange. ${ }^{74}$ Efforts to strengthen this link between partners - particularly those close to each other in age - may lay an important foundation in creating the first year of marriage as a safety or health zone.

\section{Decreasing the imminent pressure for pregnancy}

Perhaps the greatest challenge to making sex within marriage safe is to find ways to increase the acceptability of delaying childbearing. Changing the dynamics of the first year, or years, of marriage is likely to be difficult, despite the fact that overall family size desires have declined. A potential message is that while the couple is "getting to know one another" - and there is still doubt about HIV status - pregnancy should be deferred. We propose that it may be worthwhile in many settings to characterise the first year of marriage as a "health zone" on the part of public health professionals. Framing delayed childbearing in terms of protecting future fertility and ensuring that children grow up in a stable and healthy family may make this approach more accepted. $^{75}$

Campaigns to establish the first year of marriage as a "health zone" and one of deferred pregnancy can make "health" sense, but the individual bride will have little leverage in pushing for deferred childbearing. The bride and her allies (which could include a husband who also wishes to delay childbearing) will need social support. Strategies that reduce risks to the individuals, as described below, may be necessary lest deferred childbearing bring increased vulnerability to divorce and rejection to the individual bride.

There are interesting parallels between the difficulties faced by an individual young woman seeking to delay marriage or to defer childbearing and that of an individual sex worker seeking to use condoms with her clients. Both individuals are likely to bear a penalty for being among the first to initiate these innovative behavioural changes, resulting in either decreased marriageability in the case of the potential young bride or loss of income in the instance of the sex worker. A variety of collective-action strategies have worked effectively for sex workers in several countries. Recently, well-documented experiments directed at social mobilisation and collective protection strategies have been undertaken in the Dominican Republic, India, and Thailand to reduce the individual costs to sex workers of employing condoms with their clients. Originally in Thailand, HIV-prevention messages urging condom use were focused on individual sex workers. Adopting these messages raised the relative cost of doing business to them as individuals as many clients preferred commercial sex without condoms. Placing the impetus for condom use on the individual sex worker was not only unfair, it was also unsuccessful. What worked was to move the onus of condom usage from the individual sex worker to the brothel owners, who were held accountable for the level of STIs and HIV infections in all of their workers. Workers were tested at one point and treated, and the brothel owner was penalised should there be any increase in STI/HIV infection. ${ }^{76}$

\footnotetext{
${ }^{73}$ Sundari Ravindran, T.K. 2001. "Programming for low-income married adolescents: An experience from rural Tamil Nadu, India." Geneva: WHO, Department of Gender and Women's Health.

${ }^{74}$ Ravindran. 2001. See note 73.

${ }^{75}$ Brady, Martha. 2003. "Differentiating risk perception and protection needs of young women across the marital transition," draft paper presented at the WHO/UNFPA/Population Council Technical Consultation on Married Adolescents, WHO, Geneva, 9-12 December.

76 "Can solidarity and government policy reduce HIV risk in sex work?" Horizons Report, May 2002. Washington, DC: Population Council, pp. 1-3.
} 
A similar approach in the Dominican Republic, operating with newly formed sex workers' rights organisations implemented in 34 sex establishments, required 100 percent condom use in all commercial sex acts. An investigator commenting on the recorded decline of STIs noted, "The data indicate that solidarity-building activities create an enabling environment combined with government policy can result in greater changes and protective behavior and reductions in HIV vulnerability among sex workers and their clients" (p. 3). ${ }^{77}$

In Calcutta, working through a revolutionary sex workers' union called Sonagachi, the "social capital" of sex workers was built up by moving beyond an individually oriented healthpromotion model to a collective, community-development strategy. By unionising, sex workers were able to dramatically increase condom use and reduce the presence of syphilis and HIV. ${ }^{78}$

The comparison of the situation of the young, married woman and the sex worker may not be as much of a stretch as it seems. Similar arguments have been used to encourage communitylevel programmes to eliminate FGC on the grounds that the cost to an individual girl of forgoing this tradition was too high (in terms of marriageability) unless all girls in this village acted together. A similar social cohesion model that collectivises risks, reduces isolation, and minimises personal costs of adopting new positive protective behaviours, may well be the best means to enable young girls to defer marriage and defer pregnancy within marriage.

\section{Destigmatising condoms and protection from STIs/HIV within marriage}

Numerous studies have argued that condoms are unacceptable within marriage, but the rise in condom use within marriage in some settings refutes these beliefs. ${ }^{79}$ While inclusion of condoms as the main contraceptive method or as part of dual or triple protection may be difficult, ${ }^{80}$ it may be possible to increase condom use in marriage in some cultures if we reshape the image of condoms to represent not distrust or infidelity but rather respecting a partner's health, protecting one's own health, and preserving future fertility. Emphasising the link between infertility and HIV may prove compelling as new studies have shown that HIV-positive women are less than a third as likely to conceive as HIV-negative women. ${ }^{81}$

For example, while condoms have been a relatively low priority in China's official family planning programme, which has been primarily concerned with the timing, spacing, and limiting of pregnancies rather than disease prevention, condom use during the first year of marriage may be a feasible policy option in China. In light of growing HIV concerns, health workers could shift their message toward recommending and supplying condoms for the first years of marriage, offering couples an expanded choice, but also providing protection against future illness and infertility.

\footnotetext{
77 “Can solidarity and government policy reduce HIV risk in sex work?" See note 76.

78 "From health promotion to community development: Sex work study finds significant associations between social capital and safer sex," Horizons Report, May 2002. Washington, DC: Population Council, pp. 4-7.

${ }^{79}$ Maharaj, Pranitha and John Cleland. 2003. "The quiet revolution: Condom use within marriage," working paper presented at the seminar Taking Stock of the Condom in the Era of HIV/AIDS, Gabarone, Botswana, 13-17 July; and Clark, Shelley. 2003. "Suspicion, infidelity and HIV among married couples in Malawi," paper presented at the Population Association of America annual meeting, Minneapolis, 1-3 May.

${ }^{80}$ Brady. 2003. See note 75.

${ }^{81}$ Glynn, Judith, Anne Buvé, Michel Caraël et al. 2000. "Decreased fertility among HIV-1-infected women attending antenatal clinics in three African cities," Journal of Acquired Immune Deficiency Syndromes 25(4): 345 352.
} 
The married adolescents'/first-time parents' agenda, as part of an HIV-prevention effort, has the potential to bring into prominence important reproductive health technologies that have been only minimally positioned to function within $\mathrm{MCH}$ systems: condoms (male and female) and microbicides. It may be through $\mathrm{MCH}$ interventions, explicitly supportive of healthier young marriages and first-time parenthood, that condoms could be introduced as a natural part of marital sexual relations. The female condom could plausibly be introduced as a means of protecting maternal and child health during pregnancy while relations continue, which could destigmatise its close association, in some settings, with sex work. And, finally, the quintessential audience for the long-sought microbicides is young, married women under the most intense pressure to become pregnant, but who do not want to get, or pass on to their offspring, HIV infection.

\section{First Births and Beyond}

\section{Refining maternal health and adolescent sexual and reproductive health services} to bring married adolescents into the circle

To date, adolescent sexual and reproductive health programmes have either ignored the needs of married adolescent girls or assumed these were identical to those of unmarried adolescents. ${ }^{82}$ Similarly, MCH services - the key vehicle for nominally "adult" reproductive health supporthave made minimal, if any, efforts to reach the youngest married women (and their partners).

Though the youngest married women are theoretically in the purview of these services, they may not actually be the recipients of relevant care in a timely fashion. The youngest married women often have many layers of typically ill-informed authority —often in the home, through husbands, mothers-in-law, and so forth-between them and the antenatal, delivery, and postpartum services they need. ${ }^{83} \mathrm{MCH}$ services, which are often extensive even in the poorest countries, could be reconfigured to give priority attention to the youngest and first-time mothers, lending significant new energy to safe motherhood initiatives, reviving interest in them, and rendering them more relevant as shifting demographic, cultural, and health issues, especially HIV/AIDS prevention, are taken into consideration. (For more discussion, see the paper by Miller and Lester presented at this meeting.) Thus, in a country like India where adolescent sexual and reproductive health programmes are still being framed and articulated, there might be several opportunities to emphasise the needs of adolescent mothers within the existing safe motherhood initiatives, including those supporting not only testing for HIV during antenatal screening but also making antiretroviral treatment available to prevent mother-to-childtransmission of HIV. New policies could build on these programmes by prioritising the youngest, and often most fertile, married women in these services and offering extensive information about HIV/AIDS.

\section{Creating awareness of HIV and enhancing safety within marriage through} services at first birth

Intervening during the first pregnancy is justified not only by the objective risk it carries, but also because it is an opportune social and psychological moment to lay a foundation for future

\footnotetext{
${ }^{82}$ Santhya and Jejeebhoy. 2003. See note 46.

${ }^{83}$ Miller and Lester. 2003. See note 38.
} 
positive reproductive health habits. In a number of settings, practices pursued during the first pregnancy regarding delivery, infant feeding, child spacing, the prevention and treatment of STIs, early child health including immunizations, and couple communication set a precedent, positive or negative, for future pregnancies. ${ }^{84}$

For individual young wives, first pregnancies can become empowering experiences, instead of being fraught with uncertainty and anxiety. Since the first birth is a life-altering event for both young women and their husbands, giving them (ideally in collaboration with committed husbands) a greater sense of control at this point can have a profound effect on their future sexual and reproductive health. If these young women have not yet been reached, first pregnancies provide a timely and potentially powerful opportunity to provide essential information about HIV. As a matter of policy, all women attending family planning and antenatal care should have access to and be offered HIV testing and counseling. Intervention during first pregnancy can set the stage for the future dialogue and joint decisionmaking that are crucial to the long-term well-being of not only both spouses, but also of their future children. ${ }^{85}$

\section{SUMMARY}

Married adolescent girls are outside the conventionally defined research interests, policy diagnosis, and basic interventions (family life education, youth centres, peer education, and youth-friendly health services) that have underpinned adolescent reproductive health programming and many HIV/AIDS prevention activities. They are an isolated, often numerically large, and extremely vulnerable segment of the population, largely untouched by current intervention strategies.

In many countries, early marriage is a multifaceted assault on girls' rights and may serve as a bridge for the HIV virus into the general population. Promoting later marriage, to at least age 18, and shoring up the protection options including condoms and, when they become available, microbicides, ${ }^{86}$ within marriage may be essential means of preventing epidemics in countries where HIV is currently concentrated in subpopulations and of stemming the epidemic in countries where HIV has already become a common feature within marriage.

These measures could help marriage fulfill its idealised role as a protective haven from many of life's dangers, and particularly from HIV. In order to make marriage safe, however, we must first be willing to recognise an unpleasant reality that currently for many it is not. Denying the risks of marriage and holding interventions at bay outside the private sphere of marriage will not save it as an institution or protect those inside it from the increasing threat of HIV.

\footnotetext{
${ }^{84}$ Haberland, Nicole. 2003. "The neglected majority: Married adolescents," in Adolescent and Youth Sexual and Reproductive Health: Charting Directions for a Second Generation of Programming, background document for a workshop of UNFPA in collaboration with the Population Council. New York: Population Council.

${ }^{85}$ Graft, Auralice et al. 2003. "Addressing married adolescents' needs: A review of programs," and Haberland, Nicole, Erica Chong, and Hillary Bracken. 2003. "Married adolescents: An overview," draft papers prepared for the WHO/UNFPA/Population Council Technical Consultation on Married Adolescents, WHO, Geneva, 9-12 December.

${ }^{86}$ Given the pressure and desire for children, microbicides are a particularly appealing option. For pregnancy and infection prevention, condoms (male and female) are ideal.
} 
Table 1. Percentage married and probability of having unprotected sex among different groups of adolescent girls aged 15-19, by country

\begin{tabular}{|c|c|c|c|c|c|c|c|c|c|c|}
\hline Country & & $\begin{array}{c}\% \text { married } \\
\text { among all girl }\end{array}$ & $\begin{array}{l}\% \text { married } \\
\text { among } \\
\text { sexually } \\
\text { active girls }\end{array}$ & $\begin{array}{c}\% \text { married } \\
\text { among girls who } \\
\text { had sex } \\
\text { last week }\end{array}$ & $\begin{array}{c}\text { Column 4 } \\
\text { \% married } \\
\text { among girls who } \\
\text { had unprotected } \\
\text { sex } \\
\text { last week }\end{array}$ & $\begin{array}{c}\text { Column } 5 \\
\% \text { of } \\
\text { married } \\
\text { girls who } \\
\text { had } \\
\text { unprotected } \\
\text { sex last week }\end{array}$ & $\begin{array}{c}\text { Column } 6 \\
\% \text { of all } \\
\text { unmarried } \\
\text { girls who } \\
\text { had } \\
\text { unprotected } \\
\text { sex last week }\end{array}$ & $\begin{array}{c}\text { Column } 7 \\
\text { active } \\
\text { unmarried girls } \\
\text { who had } \\
\text { unprotected } \\
\text { sex } \\
\text { last week }\end{array}$ & $\begin{array}{l}\text { Column } 8 \\
\text { Relative risk of } \\
\text { having } \\
\text { unprotected sex } \\
\text { last week } \\
\text { (Column 5/ } \\
\text { Column 6) } \\
\end{array}$ & $\underline{\text { Column } 9}$ \\
\hline \multicolumn{11}{|c|}{ South and East Africa } \\
\hline Ethiopia & 2000 & 24.9 & 94.2 & 97.2 & 97.9 & 73.6 & 0.5 & 25.9 & 141.6 & 3366 \\
\hline Kenya & 1998 & 15.6 & 36.4 & 69.2 & 72.3 & 63.4 & 4.5 & 13.9 & 14.1 & 1827 \\
\hline Malawi & 2000 & 34.0 & 61.4 & 90.9 & 92.6 & 63.1 & 2.6 & 8.0 & 24.3 & 2788 \\
\hline Mozambique & 1997 & 45.9 & 66.7 & 80.2 & 82.0 & 40.2 & 7.5 & 17.7 & 5.4 & 1816 \\
\hline Rwanda & 2000 & 6.6 & 50.9 & 96.8 & 97.2 & 88.5 & 0.2 & 2.6 & 491.4 & 2713 \\
\hline South Africa & 1998 & 3.3 & 7.3 & 12.4 & 12.6 & 33.6 & 7.9 & 18.4 & 4.3 & 2357 \\
\hline Tanzania & 1999 & 25.6 & 49.6 & 75.5 & 77.0 & 61.1 & 6.3 & 18.0 & 9.7 & 909 \\
\hline Uganda & 1995 & 48.4 & 80.1 & 95.1 & 96.3 & 65.6 & 2.4 & 10.1 & 27.7 & 1578 \\
\hline Zambia & 2001/02 & 24.9 & 44.4 & 80.9 & 81.7 & 54.9 & 4.1 & 9.8 & 13.4 & 1756 \\
\hline Zimbabwe & 1999 & 21.9 & 68.7 & 93.6 & 94.7 & 63.9 & 1.0 & 7.9 & 63.9 & 1454 \\
\hline \multicolumn{11}{|l|}{ West Africa } \\
\hline Benin & 2001 & 23.4 & 42.2 & 64.0 & 68.1 & 36.2 & 5.2 & 12.4 & 7.0 & 1216 \\
\hline Burkina Faso & 1998/99 & 34.2 & 70.4 & 79.2 & 86.0 & 35.7 & 3.0 & 13.8 & 11.9 & 1461 \\
\hline Cameroon & 1998 & 34.3 & 53.4 & 67.3 & 69.9 & 44.6 & 10.0 & 22.0 & 4.4 & 1269 \\
\hline Gabon & 2000 & 18.9 & 27.5 & 46.7 & 53.2 & 48.3 & 9.9 & 16.1 & 4.9 & 1552 \\
\hline Ghana & 1998 & 13.8 & 37.7 & 46.7 & 49.0 & 24.9 & 4.2 & 16.0 & 6.0 & 866 \\
\hline Guinea & 1999 & 44.6 & 75.3 & 80.4 & 84.0 & 39.7 & 6.1 & 23.1 & 6.5 & 1317 \\
\hline Mali & 2001 & 47.2 & 74.8 & 88.9 & 89.6 & 54.7 & 5.7 & 19.0 & 9.6 & 2477 \\
\hline Nigeria & 1999 & 15.6 & 60.8 & 87.1 & 89.3 & 47.2 & 1.0 & 9.1 & 45.4 & 3365 \\
\hline Senegal & 1999 & 28.1 & 82.5 & 95.1 & N/A & N/A & N/A & N/A & N/A & 1935 \\
\hline \multicolumn{11}{|c|}{ Latin America and the Caribbean } \\
\hline Brazil & 1996 & 14.2 & 46.3 & 67.7 & 71.7 & 77.1 & 5.1 & 26.3 & 15.3 & 2453 \\
\hline Colombia & 2000 & 14.9 & 39.0 & 69.2 & 77.6 & 75.6 & 3.8 & 14.0 & 19.8 & 2192 \\
\hline Dominican Republic & 1999 & 19.6 & 77.6 & 89.5 & 95.6 & 48.3 & 0.5 & 7.7 & 89.4 & 249 \\
\hline Guatemala & 1998/99 & 24.3 & 94.5 & 99.7 & 100.0 & 55.8 & 0.0 & 0.0 & 0.0 & 1366 \\
\hline Haiti & 2000 & 16.6 & 51.9 & 78.3 & 82.6 & 27.8 & 1.2 & 6.3 & 23.8 & 2367 \\
\hline Nicaragua & 2001 & 24.3 & 83.3 & 97.0 & 97.3 & 70.8 & 0.6 & 9.8 & 112.3 & 3074 \\
\hline Peru & 2000 & 10.4 & 48.4 & 79.5 & 81.2 & 63.6 & 1.7 & 13.8 & 37.2 & 5679 \\
\hline \multicolumn{11}{|l|}{ Asia } \\
\hline Bangladesh & $1999 / 2000$ & N/A & N/A & N/A & N/A & N/A & N/A & N/A & N/A & 1571 \\
\hline India & 1998/99 & N/A & N/A & N/A & N/A & N/A & N/A & N/A & N/A & 6888 \\
\hline Indonesia & 1997 & N/A & N/A & N/A & N/A & N/A & N/A & N/A & N/A & 1066 \\
\hline \multicolumn{11}{|l|}{ Middle East } \\
\hline Egypt & 2000 & N/A & N/A & N/A & N/A & N/A & N/A & N/A & N/A & 579 \\
\hline Turkey & 1999 & 15.3 & N/A & N/A & N/A & $\mathrm{N} / \mathrm{A}$ & $\mathrm{N} / \mathrm{A}$ & N/A & N/A & 1759 \\
\hline
\end{tabular}

${ }^{1}$ Formerly married adolescent girls are excluded from all analyses. 
Table 2. Percentage of sexually active girls seeking pregnancy in the next two years, by parity and marital status

\begin{tabular}{|c|c|c|c|c|c|c|}
\hline & Column 1 & $\underline{\text { Column } 2}$ & Column 3 & Column 4 & Column 5 & $\underline{\text { Column } 6}$ \\
\hline Country & $\begin{array}{c}\text { Married, } \\
\text { nulliparous }\end{array}$ & $\begin{array}{l}\text { Unmarried, } \\
\text { nulliparous }\end{array}$ & Sig. ${ }^{1}$ & $\begin{array}{c}\text { Married, } \\
\text { parous }\end{array}$ & $\begin{array}{l}\text { Unmarried, } \\
\text { parous }^{2}\end{array}$ & Sig. ${ }^{1}$ \\
\hline \multicolumn{7}{|c|}{ South and East Africa } \\
\hline Ethiopia & 43.6 & 12.2 & $* * *$ & 15.5 & 0.0 & \\
\hline Kenya & 47.1 & 8.2 & $* * *$ & 15.4 & 8.2 & $*$ \\
\hline Malawi & 47.3 & 8.6 & $* * *$ & 13.2 & 2.6 & ** \\
\hline Mozambique & 59.5 & 19.0 & $* * *$ & 30.7 & 7.9 & $* * *$ \\
\hline Rwanda & 43.2 & 10.0 & $* * *$ & 15.1 & 0.0 & $*$ \\
\hline South Africa & 26.1 & 1.4 & $* * *$ & 0.0 & 1.2 & \\
\hline Tanzania & 65.1 & 19.9 & $* * *$ & 26.8 & 14.7 & + \\
\hline Uganda & 48.0 & 16.3 & $* * *$ & 24.4 & 14.6 & \\
\hline Zambia & 53.0 & 28.1 & $* * *$ & 24.7 & 8.6 & $* * *$ \\
\hline Zimbabwe & 57.8 & 33.0 & $* * *$ & 9.3 & 1.6 & + \\
\hline \multicolumn{7}{|l|}{ West Africa } \\
\hline Benin & 44.9 & 7.1 & $* * *$ & 18.6 & 8.1 & \\
\hline Burkina Faso & 60.6 & 18.3 & $* * *$ & 16.3 & 14.4 & \\
\hline Cameroon & 52.5 & 17.8 & $* * *$ & 33.9 & 5.1 & $* * *$ \\
\hline Gabon & 38.3 & 10.9 & $* * *$ & 14.0 & 4.3 & $* *$ \\
\hline Ghana & 23.7 & 10.2 & $* *$ & 9.9 & 0.0 & \\
\hline Guinea & 61.9 & 15.2 & $* * *$ & 35.7 & 0.0 & $* * *$ \\
\hline Mali & 57.1 & 28.2 & $* * *$ & 23.4 & 3.2 & $* * *$ \\
\hline Nigeria & 61.1 & 4.0 & $* * *$ & 39.7 & 5.1 & $* * *$ \\
\hline Senegal & 58.8 & 0.0 & $* * *$ & 17.5 & 0.0 & $* *$ \\
\hline \multicolumn{7}{|c|}{ Latin America and the Caribbean } \\
\hline Brazil & 29.9 & 11.7 & $* * *$ & 5.4 & 0.0 & $*$ \\
\hline Colombia & 24.5 & 7.0 & $* * *$ & 4.1 & 1.3 & \\
\hline Dominican Republic & 29.5 & 12.6 & & 10.8 & 63.7 & $*$ \\
\hline Guatemala & 44.9 & 33.0 & & 12.6 & 0.0 & \\
\hline Haiti & 6.7 & 3.3 & + & 7.7 & 3.4 & \\
\hline Nicaragua & 30.6 & 3.5 & $* * *$ & 8.0 & 1.0 & + \\
\hline Peru & 16.4 & 3.6 & $* * *$ & 1.8 & 1.1 & \\
\hline \multicolumn{7}{|l|}{ Asia } \\
\hline Bangladesh & 39.4 & $\mathrm{~N} / \mathrm{A}$ & $\mathrm{N} / \mathrm{A}$ & 11.3 & $\mathrm{~N} / \mathrm{A}$ & $\mathrm{N} / \mathrm{A}$ \\
\hline India & 95.1 & $\mathrm{~N} / \mathrm{A}$ & $\mathrm{N} / \mathrm{A}$ & 79.7 & $\mathrm{~N} / \mathrm{A}$ & $\mathrm{N} / \mathrm{A}$ \\
\hline Indonesia & 52.2 & $\mathrm{~N} / \mathrm{A}$ & $\mathrm{N} / \mathrm{A}$ & 10.3 & $\mathrm{~N} / \mathrm{A}$ & $\mathrm{N} / \mathrm{A}$ \\
\hline \multicolumn{7}{|l|}{ Middle East } \\
\hline Egypt & 59.1 & $\mathrm{~N} / \mathrm{A}$ & N/A & 16.7 & $\mathrm{~N} / \mathrm{A}$ & $\mathrm{N} / \mathrm{A}$ \\
\hline Turkey & 54.6 & N/A & $\mathrm{N} / \mathrm{A}$ & 9.0 & $\mathrm{~N} / \mathrm{A}$ & $\mathrm{N} / \mathrm{A}$ \\
\hline
\end{tabular}


Table 3. Percentage of girls aged 15-19 who had unprotected sex last week, by marital status and desire to become pregnant in the next two years

\begin{tabular}{|c|c|c|c|c|c|c|}
\hline & Column 1 & $\underline{\text { Column } 2}$ & Column 3 & $\underline{\text { Column } 4}$ & $\underline{\text { Column } 5}$ & $\underline{\text { Column } 6}$ \\
\hline Country & $\begin{array}{c}\text { Married, } \\
\text { desire } \\
\text { pregnancy } \\
\end{array}$ & $\begin{array}{c}\text { Unmarried, } \\
\text { desire } \\
\text { pregnancy } \\
\end{array}$ & Sig. ${ }^{1}$ & $\begin{array}{c}\text { Married, } \\
\text { do not desire } \\
\text { pregnancy }\end{array}$ & $\begin{array}{c}\text { Unmarried, } \\
\text { do not } \\
\text { pregnancy }\end{array}$ & Sig. ${ }^{1}$ \\
\hline \multicolumn{7}{|c|}{ South and East Africa } \\
\hline Ethiopia & 88.9 & 8.0 & & 67.5 & 0.8 & $* * *$ \\
\hline Kenya & 82.0 & 19.6 & $* * *$ & 56.8 & 2.9 & $* * *$ \\
\hline Malawi & 79.5 & 22.2 & $* * *$ & 57.2 & 2.2 & $* * *$ \\
\hline Mozambique & 54.4 & 24.5 & $* * *$ & 31.8 & 4.7 & $* * *$ \\
\hline Rwanda & 81.9 & 0.0 & $* * *$ & 92.4 & 0.1 & $* * *$ \\
\hline South Africa & 70.6 & 43.1 & & 28.0 & 7.2 & + \\
\hline Tanzania & 80.2 & 9.9 & $* * *$ & 45.1 & 6.3 & $* * *$ \\
\hline Uganda & 80.4 & 9.0 & $* * *$ & 58.5 & 2.3 & $* * *$ \\
\hline Zambia & 68.4 & 23.8 & $* * *$ & 47.5 & 3.4 & $* * *$ \\
\hline Zimbabwe & 70.5 & 2.7 & $* * *$ & 60.3 & 0.7 & $* * *$ \\
\hline \multicolumn{7}{|l|}{ West Africa } \\
\hline Benin & 62.9 & 12.9 & $* * *$ & 24.2 & 6.8 & $* * *$ \\
\hline Burkina Faso & 67.3 & 27.1 & $* * *$ & 18.2 & 1.0 & $*$ \\
\hline Cameroon & 62.0 & 45.9 & + & 32.2 & 5.7 & $* * *$ \\
\hline Gabon & 69.8 & 28.8 & $* * *$ & 39.5 & 9.3 & $* * *$ \\
\hline Ghana & 78.0 & 26.1 & $* *$ & 17.3 & 4.4 & \\
\hline Guinea & 58.8 & 40.6 & & 23.9 & 1.9 & \\
\hline Mali & 67.0 & 15.0 & $* * *$ & 54.4 & 5.4 & $* * *$ \\
\hline Nigeria & 56.7 & 24.8 & + & 40.7 & 0.4 & $* * *$ \\
\hline Senegal & $\mathrm{N} / \mathrm{A}$ & N/A & $\mathrm{N} / \mathrm{A}$ & N/A & N/A & $\mathrm{N} / \mathrm{A}$ \\
\hline \multicolumn{7}{|c|}{ Latin America and the Caribbean } \\
\hline Brazil & 71.4 & 36.6 & $* *$ & 78.1 & 4.1 & $* * *$ \\
\hline Colombia & 88.2 & 21.7 & $* * *$ & 74.0 & 3.6 & $* * *$ \\
\hline Dominican Republic & 79.1 & 0.0 & $* *$ & 40.5 & 0.5 & \\
\hline Guatemala & 67.6 & 0.0 & + & 52.3 & 0.0 & $* * *$ \\
\hline Haiti & 36.6 & 21.7 & & 27.3 & 1.2 & $* * *$ \\
\hline Nicaragua & 92.4 & 1.1 & $* * *$ & 66.7 & 0.7 & $* * *$ \\
\hline Peru & 83.8 & 14.4 & $* * *$ & 62.2 & 1.7 & $* * *$ \\
\hline \multicolumn{7}{|l|}{ Asia } \\
\hline Bangladesh & N/A & $\mathrm{N} / \mathrm{A}$ & N/A & N/A & $\mathrm{N} / \mathrm{A}$ & N/A \\
\hline India & N/A & N/A & N/A & N/A & N/A & N/A \\
\hline Indonesia & N/A & N/A & N/A & N/A & N/A & $\mathrm{N} / \mathrm{A}$ \\
\hline \multicolumn{7}{|l|}{ Middle East } \\
\hline Egypt & N/A & N/A & N/A & N/A & N/A & N/A \\
\hline Turkey & N/A & N/A & N/A & N/A & N/A & N/A \\
\hline
\end{tabular}


Table 4. Age at first marriage and age differences between spouses

\begin{tabular}{|c|c|c|c|c|c|c|c|}
\hline Country & $\begin{array}{c}\text { Legal } \\
\text { minimum } \\
\text { age of marriage }\end{array}$ & $\begin{array}{l}\% \text { married } \\
\text { by age } 15^{2}\end{array}$ & $\begin{array}{l}\% \text { married } \\
\text { by age } 18^{2}\end{array}$ & $\begin{array}{l}\% \text { married } \\
\text { by age } 20^{2}\end{array}$ & $\begin{array}{l}\text { Column } 5 \\
\text { Median interval } \\
\text { (mo.) betw. } \\
\text { marriage and first } \\
\text { birth among } \\
\text { women married } \\
\text { before age } 20\end{array}$ & $\begin{array}{c}\text { Column 6 } \\
\text { Mean age } \\
\text { difference } \\
\text { (years) with } \\
\text { husband if wife } \\
\text { marries } \\
\text { before age } 20\end{array}$ & $\begin{array}{c}\text { Column } 7 \\
\text { Mean age } \\
\text { difference } \\
\text { (years) with } \\
\text { husband if wife } \\
\text { marries at or } \\
\text { after age 20 }\end{array}$ \\
\hline
\end{tabular}

South and East Africa

30.6

Malawi

Mozambique

Rwanda

South Africa

Tanzania

Uganda

Zambia

Zimbabwe

Benin

$\begin{array}{lll}\text { Burkina Faso } & 18 & 12.0 \\ \text { Caneron } & 18 & 7.9\end{array}$

$\begin{array}{lll}\text { Burkina Faso } & 18 & 7.9\end{array}$

Cameroon

Gabon

Ghana

Guinea

Mali

varies

Nigeria

15

Senegal

16

$\begin{array}{ll}70.2 & 82.5 \\ 38.7 & 57.4 \\ 52.2 & 75.3 \\ 59.4 & 75.1 \\ 20.0 & 42.3 \\ 14.0 & 26.8 \\ 48.9 & 68.7 \\ 56.5 & 74.6 \\ 52.2 & 72.2 \\ 33.9 & 57.9\end{array}$

$\begin{array}{lll}28.0 & 8.7 & 7.6 \\ 14.0 & 7.9 & 5.8\end{array}$

Latin America and the Caribbean

Brazil

Colombia

Dominican Republic

Guatemala

Haiti

Nicaragua

30.6
13.2
15.4

2.5

14.0

14.0
22.0
14.0

14.0

19.0

15.0

16.0
14.0

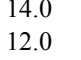

$\begin{array}{ll}7.9 & 7.6 \\ 5.7 & 5.8\end{array}$

41.7

57.9

12.0

7.9
5.7

7.7

6.3
6.2

$\mathrm{N} / \mathrm{A}$

N/A

6.7
8.3

4.8

6.8

4.4
4.6

4.6
$\mathrm{~N} / \mathrm{A}$

$\mathrm{N} / \mathrm{A}$

$\mathrm{N} / \mathrm{A}$
5.9

5.9
6.0

Peru

Bangladesh

India

Indonesia

Middle East

$\begin{array}{ll}63.1 & 61.5 \\ 56.4 & 84.6\end{array}$

13.0

$\begin{array}{lll}56.4 & 71.9 & 23.0\end{array}$

$\begin{array}{lll}56.4 & 52.5 & 23.0 \\ 37.8 & 52.5 & 25.0\end{array}$

$\begin{array}{lll}37.8 & 52.5 & 25.0 \\ 37.8 & 59.4 & 15.0 \\ 66.9 & 80.9 & 19.0\end{array}$

$\begin{array}{ll}66.9 & 80.9 \\ 65.6 & 79.4\end{array}$

$\begin{array}{ll}60.4 & 63.8\end{array}$

15.0
19.0

21.0
23.0

$\begin{array}{rr}9.5 & 7.4 \\ 11.5 & 8.0\end{array}$

55.1

63.8
69.2

21.0

11.5
11.1
8.5

7.4
8.0
7.6

$\begin{array}{ll}8.5 & 7.0 \\ 14.1 & \end{array}$

Egypt

$\begin{array}{ll}21 & 4.0\end{array}$

$\begin{array}{ll}22.7 & 40.4\end{array}$

22.7

37.9

37.8

27.9
48.5

23.4

$\begin{array}{ll}40.4 & 15.0\end{array}$

N/A N/A

${ }^{1}$ Source: http://www.jhuccp.org/pr/j41/j41table2.shtml.

${ }^{2}$ Calculated with women over age 25 . 
Table 5. HIV knowledge, education, and protective strategies for married and unmarried girls

\begin{tabular}{|c|c|c|c|c|c|c|c|c|c|c|c|}
\hline Country & $\begin{array}{l}\% \text { heard } \\
\text { of HIV } \\
\text { (married) }\end{array}$ & $\begin{array}{l}\text { Column } 2 \\
\% \text { heard } \\
\text { of HIV } \\
\text { (unmarried) }\end{array}$ & $\begin{array}{c}\text { Column } 3 \\
\% \text { knows one } \\
\text { way to } \\
\text { avoid AIDS } \\
\text { (married) } \\
\end{array}$ & $\begin{array}{c}\text { Column } 4 \\
\% \text { knows one } \\
\text { way to } \\
\text { avoid AIDS } \\
\text { (unmarried) } \\
\end{array}$ & $\begin{array}{l}\text { Column } 5 \\
\text { First most com- } \\
\text { mon behavioural } \\
\text { change } \\
\text { (married) }\end{array}$ & $\begin{array}{c}\text { Column } 6 \\
\text { First most com- } \\
\text { mon behavioural } \\
\text { change } \\
\text { (unmarried) }\end{array}$ & $\begin{array}{c}\text { Column } 7 \\
\text { Second most com- } \\
\text { mon behavioural } \\
\text { change } \\
\text { (married) } \\
\end{array}$ & $\begin{array}{c}\text { Column } 8 \\
\text { Second most com- } \\
\text { mon behavioural } \\
\text { change } \\
\text { (unmarried) } \\
\end{array}$ & $\begin{array}{c}\text { Column 9 } \\
\% \text { think } \\
\text { beating wife } \\
\text { justified if } \\
\text { sex withheld }^{1} \\
\end{array}$ & $\begin{array}{c}\text { Column } 10 \\
\% \text { of } \\
\text { married } \\
\text { adolescents } \\
\text { in school } \\
\end{array}$ & $\begin{array}{c}\text { Column 11 } \\
\% \text { of } \\
\text { unmarried } \\
\text { adolescents } \\
\text { in school } \\
\end{array}$ \\
\hline \multicolumn{12}{|l|}{ South and East Africa } \\
\hline Ethiopia & 83.2 & 77.7 & 68.3 & 64.4 & N/A & N/A & N/A & N/A & 43.3 & N/A & N/A \\
\hline Kenya & 98.1 & 98.8 & 77.4 & 74.6 & Only one partner & Did not start sex & None & None & N/A & 2.0 & 59.7 \\
\hline Malawi & 99.0 & 97.8 & 91.3 & 91.5 & N/A & N/A & N/A & N/A & 16.9 & N/A & N/A \\
\hline Mozambique & 80.6 & 82.4 & 27.9 & 34.2 & Only one partner & Did not start sex & None & None & N/A & 2.2 & 28.9 \\
\hline Rwanda & 99.6 & 99.2 & 93.6 & 93.0 & Only one partner & Abstained & Abstained & None & 25.0 & N/A & N/A \\
\hline South Africa & 87.1 & 95.4 & 97.0 & 96.0 & N/A & N/A & N/A & N/A & N/A & 37.7 & 81.6 \\
\hline Tanzania & 92.8 & 95.8 & 77.0 & 77.3 & Only one partner & Abstained & Abstained & Only one partner & N/A & 0.0 & 36.1 \\
\hline Uganda & 98.7 & 98.6 & 83.6 & 87.6 & Only one partner & Stopped all sex & Reduced partners & Only one partner & N/A & 1.2 & 41.6 \\
\hline Zambia & 99.1 & 98.1 & 78.8 & 78.3 & N/A & N/A & N/A & N/A & 41.1 & N/A & N/A \\
\hline Zimbabwe & 94.2 & 94.6 & 74.4 & 80.8 & N/A & $\mathrm{N} / \mathrm{A}$ & N/A & N/A & 16.7 & N/A & N/A \\
\hline \multicolumn{12}{|l|}{ West Africa } \\
\hline Benin & 91.3 & 95.5 & 56.1 & 57.5 & N/A & N/A & N/A & N/A & 15.2 & N/A & N/A \\
\hline Burkina Faso & 81.9 & 79.0 & 64.4 & 65.8 & None & Did not start sex & Only one partner & None & N/A & 0.2 & 13.5 \\
\hline Cameroon & 85.9 & 91.6 & 72.8 & 79.0 & None & None & Only one partner & Did not start sex & N/A & 6.0 & 51.5 \\
\hline Gabon & 96.9 & 98.1 & 78.9 & 83.6 & None & None & Used condoms & Used condoms & N/A & 38.1 & 79.1 \\
\hline Ghana & 97.8 & 96.2 & 76.2 & 75.6 & Only one partner & Did not start sex & None & Only one partner & N/A & 3.5 & 45.1 \\
\hline Guinea & 94.7 & 96.7 & 80.5 & 80.9 & Only one partner & Did not start sex & None & Only one partner & N/A & 2.8 & 33.2 \\
\hline Mali & 88.1 & 89.8 & 48.6 & 56.6 & N/A & N/A & N/A & N/A & 63.9 & N/A & N/A \\
\hline Nigeria & 48.4 & 63.9 & 63.9 & 60.9 & Only one partner & Did not start sex & None & None & N/A & 2.3 & 70.9 \\
\hline Senegal & 84.2 & 92.4 & 54.6 & 68.1 & N/A & N/A & N/A & N/A & N/A & N/A & N/A \\
\hline \multicolumn{12}{|c|}{ Latin America and the Caribbean } \\
\hline Brazil & 99.7 & 99.1 & 82.5 & 90.4 & None & None & Only one partner & Did not start sex & N/A & 11.1 & 75.0 \\
\hline Colombia & 93.8 & 97.7 & 78.4 & 89.5 & N/A & N/A & N/A & N/A & N/A & N/A & N/A \\
\hline Dominican Republic & 100.0 & 99.5 & 88.2 & 85.9 & Only one partner & Only one partner & Used condoms & Used condoms & 1.5 & 38.5 & 91.5 \\
\hline Guatemala & N/A & $\mathrm{N} / \mathrm{A}$ & $\mathrm{N} / \mathrm{A}$ & $\mathrm{N} / \mathrm{A}$ & N/A & N/A & N/A & N/A & $\mathrm{N} / \mathrm{A}$ & 2.9 & 45.6 \\
\hline Haiti & 98.8 & 96.9 & 50.4 & 53.8 & None & None & Only one partner & Abstains & 10.8 & N/A & N/A \\
\hline Nicaragua & 88.8 & 92.5 & 33.8 & 40.7 & Only one partner & Did not start sex & sked partner to be faith & Only one partner & 4.5 & N/A & N/A \\
\hline Peru & 73.5 & 89.2 & 55.7 & 78.1 & N/A & N/A & N/A & N/A & N/A & N/A & N/A \\
\hline \multicolumn{12}{|l|}{ Asia } \\
\hline Bangladesh & 29.6 & N/A & 37.5 & N/A & N/A & N/A & N/A & N/A & N/A & N/A & N/A \\
\hline India & 29.7 & N/A & 59.2 & N/A & N/A & N/A & N/A & N/A & N/A & N/A & N/A \\
\hline Indonesia & 52.6 & N/A & 92.2 & N/A & None & N/A & Only one partner & $\mathrm{N} / \mathrm{A}$ & N/A & 1.3 & N/A \\
\hline \multicolumn{12}{|l|}{ Middle East } \\
\hline Egypt & $\mathrm{N} / \mathrm{A}$ & $\mathrm{N} / \mathrm{A}$ & $\mathrm{N} / \mathrm{A}$ & $\mathrm{N} / \mathrm{A}$ & N/A & N/A & N/A & $\mathrm{N} / \mathrm{A}$ & $\mathrm{N} / \mathrm{A}$ & $\mathrm{N} / \mathrm{A}$ & N/A \\
\hline Turkey & 79.5 & 84.0 & 51.4 & 64.1 & N/A & $\mathrm{N} / \mathrm{A}$ & $\mathrm{N} / \mathrm{A}$ & $\mathrm{N} / \mathrm{A}$ & 13.0 & 0.5 & 29.9 \\
\hline
\end{tabular}

${ }^{1}$ All women were asked whether a husband was justified in beating his wife if she refused to have sex with him. 
Table 6. Percentage of 15-19-year-old girls enrolled in school, by marital status and parity

\begin{tabular}{|l|c|c|c|c|}
\hline \multirow{2}{*}{ Country } & \multicolumn{2}{|c|}{ Married } & \multicolumn{2}{c|}{ Unmarried } \\
\cline { 2 - 5 } & Without children & With children & Without children & With children \\
\hline Brazil & 12.8 & 10.3 & 76.2 & 29.8 \\
\hline Haiti & 32.7 & 5.1 & 74.9 & 9.7 \\
\hline Nicaragua & 15.6 & 7.7 & 66.5 & 12.5 \\
\hline Burkina Faso & 0.0 & 0.3 & 13.5 & 2.7 \\
\hline Nigeria & 7.7 & 0.9 & 45.3 & 0.0 \\
\hline Ethiopia & 3.2 & 0.7 & 69.5 & 2.2 \\
\hline Kenya & 3.8 & 1.4 & 34.6 & 8.9 \\
\hline Mozambique & 3.7 & 1.0 & 63.4 & 5.7 \\
\hline Zimbabwe & 0.6 & 3.5 & 30.3 & 0.0 \\
\hline Kazakhstan & 2.4 & 2.0 & 56.7 & 0.0 \\
\hline
\end{tabular}

Data compiled by Erica Chong. 
Table 7. Areas and regions where early marriage is common

\begin{tabular}{|l|c|c|c|}
\hline Region, country & $\begin{array}{c}\text { Married by age 15 } \\
\text { (percent) }\end{array}$ & $\begin{array}{c}\text { Married by age 18 } \\
\text { (percent) }\end{array}$ & $\begin{array}{c}\text { Median age at } \\
\text { marriage (years) }\end{array}$ \\
\hline Amhara, Ethiopia & 50 & 80 & 15.0 \\
\hline Kayes, Mali & 39 & 83 & 15.5 \\
\hline Rajasthan, India & 36 & 68 & 16.0 \\
\hline Bihar, India & 40 & 71 & 15.7 \\
\hline Uttar Pradesh, India & 36 & 62 & 17.1 \\
\hline $\begin{array}{l}\text { Nepal } \\
\text { Far-western region }\end{array}$ & 19 & 60 & 15.9 \\
\hline $\begin{array}{l}\text { Bangladesh } \\
\text { Rajshahi division } \\
\text { Khulna division }\end{array}$ & 38 & 65 & 15.1 \\
\hline
\end{tabular}

Source: All data are for 20-24-year-olds, DHS data, 2001.

Data compiled by Erica Chong. 